Chapter 27

\title{
Current Challenges in the Treatment of Deep Sternal Wound Infection Following Cardiac Surgery
}

\author{
Martin Šimek, Martin Molitor, Martin Kaláb, \\ Patrick Tobbia and Vladimír Lonský \\ Additional information is available at the end of the chapter \\ http://dx.doi.org/10.5772/55310
}

\section{Introduction}

Median sternotomy due to its technical simplicity and excellent exposure of the heart, great vessels and pulmonary hila is the most common incision performed in cardiothoracic surgery worldwide [1]. Originally described by Julian more than 100 years ago and re-induced by Milton in 1957, median sternotomy replaced gradually thoracotomy or bilateral transverse sternothoracotomy (clamshell incision) for routine access to the heart [2,3]. Even though median sternotomy is still considered to be the gold standard, efforts remain ongoing to use less invasive methods such as partial sternotomy or small thoracotomy to influence the risk of wound healing complications, patient's satisfaction and better quality of life [4].

\section{Incidence and risk factors of Deep Sternal Wound Infection (DSWI)}

Infection involving the sternal bones and/or retrosternal space is a serious complication of median sternotomy. Although, DSWI can be described from many perspectives, the definition according to the Center for Disease Control and Prevention (CDC), is used for distinguishing DSWI from others types of sternal wound infections (SWIs), and is respected by most authors (Table 1) [5]. Looking through the incidence of DSWI ranging between 0.3 to $3.2 \%$, no considerable changes have been observed in the incidence of DSWI over the last 30 years [6-22]. It could be perceived that the numerous advances in cardiac surgery, post-operative care and employment of preventive measurements may have played a role in reducing the incidence of DSWI in the last 10 years. Today surgically treated patients' cohorts are different than patients operated on 20 years ago in terms of advanced age, co-morbidities, and surgical 
complexity. In other words, the relatively steady status of DSWI incidence over the last three decades might be considered a satisfactory result [23]. Recently Matros et al showed from a large single institution experience with 21,000 sternotomies a reduction in the incidence of DSWI from 1.57 to $0.88 \%$ in the last 15 years. They concluded that the rate of DSWI was significantly diminished particularly in the diabetic population, from $3.2 \%$ to $1.0 \%$, related to tight glycemic control [19].

Diagnosis of DSWI requires at least one of the following criteria:

(1) anorganism is isolated from culture of mediastinal tissue or fluid

(2) evidence of mediastinitis is seen during operation or byhistopathological examination

(3) one of the following, fever("/>38 C), chest pain, or sternal instability, is present

and there is either purulent drainage from the mediastinum

or an organism isolated from blood culture or culture of drainage of the mediastinal area

Table 1. Center for Disease Control and Prevention (CDC) criteria of DSWI (modified from Mangan et al[5])

The identification of risk factors for the development of DSWI is crucial in the effort to reduce the risk of infection [6-22]. Although more than two dozen factors were obtained for uni-, and multivariable analyses, only obesity and diabetes mellitus were constantly proven in published studies [6-18,21,22]. Obesity is a strong risk factor for development of DSWI. Even though BMI does not correlate closely with body fat, there is a step-wise relationship between BMI and the risk of major surgical infection in cardiac surgery $[7,15,24]$. It is caused not only through technical obesity-related problems, but also through less effective penetration of antibiotics into the fat tissue [24]. Undoubtedly, diabetics are at a higher risk of developing DSWI, making the role of perioperative glycemic control crucial. Unsatisfactory preoperative glycemic control is considered to be an important risk factor for development of DSWI [25,26]. Internal mammary artery (IMA) harvesting, particularly in the pedicled fashion, has been found to have a higher incidence of DSWI in a CABG cohort compared with valvular procedures $[7,8]$. Furthermore, this risk becomes stronger when both IMA are used for revascularization or in the diabetic population, but this effect might be attenuated when both IMA are taken down in a skeletonized fashion, even in diabetics $[10,27,28]$. Chronic obstructive pulmonary disease (COPD) or smoking increases the risk of infectious complications, prolonged post-operative ventilation, and jeopardizes sternal stability from excessive coughing [6,12,15]. Data addressing the impact of early tracheostomy on DSWI incidence is conflicting [29-31]. Historically, a strong relationship between early tracheostomy and DSWI has not been confirmed; but tracheostomy is known to reduce the need for mechanical ventilation and thereby may limit risk of pulmonary infection and ICU stay [32]. Furthermore, re-exploration for bleeding has been analyzed as an independent risk factor for DSWI in several studies [11,12]. The components of this risk factor include the risk of iatrogenic bacteriological wound contamination within the inherent re-exposure, the deleterious effect of anemia and/or concomitant hemodynamic instability, and the amount of given allogenic blood transfusion units $[10,33]$. Other 
factors traditionally associated with an increased risk of DSWI are inconsistently seen in analyses of retrospective studies including advanced age, emergency surgery, hemodynamic instability, low ejection fraction, duration of surgery and CPB time, and renal failure [6-22]. Incidence and risk factors based on multivariable analysis from larger retrospective studies are summarized in Table 2.

\begin{tabular}{|c|c|c|c|c|}
\hline Authors & $\begin{array}{l}\text { Patients' } \\
\text { enrollement }\end{array}$ & $\begin{array}{l}\text { No. of } \\
\text { patients }\end{array}$ & $\begin{array}{l}\text { DSWI } \\
\text { incidence }\end{array}$ & Independent risk factors \\
\hline Loop FD et al [6] & $1985-1987$ & 6504 & $1.1 \%$ & Obesity, BIMA+diabetes, time of operation, \\
\hline Milano CA et al [7] & 1987-1995 & 6459 & $1.3 \%$ & Obesity, CHF, re-do surgery, CPB time \\
\hline Braxton et al [8] & 1992-1996 & 15406 & $1.25 \%$ & Obesity, low EF, COPD \\
\hline Eklund et al [9] & 1990-1999 & 10713 & $1.1 \%$ & Obesity, BMI \\
\hline $\begin{array}{l}\text { The Parisian Mediastinitis } \\
\text { Study Group [10] }\end{array}$ & 1996 & 1830 & NA & $\begin{array}{l}\text { Obesity, BIMA, hemodynamic instability, re- } \\
\text { do surgery }\end{array}$ \\
\hline Hollenbeak et al [11] & 1996-1998 & 1519 & $2.7 \%$ & Obesity, renal inssuficieny, re-exploration \\
\hline Filsouri et al [12] & $1998-2005$ & 5798 & $1.80 \%$ & $\begin{array}{l}\text { Obesity, MI, diabetes, COPD, CPB time, re- } \\
\text { exploration, prolonged ventilation }\end{array}$ \\
\hline Tang et al [13] & $1990-2003$ & 30102 & $0.77 \%$ & $\begin{array}{l}\text { Age, diabetes, stroke, CHF, BIMA } \\
\text { +diabetes/CHF }\end{array}$ \\
\hline Toumpoulis et al [14] & $1992-2002$ & 3760 & $1.1 \%$ & $\begin{array}{l}\text { Diabetes, dialysis, hemodynamic instability, } \\
\text { BIMA }\end{array}$ \\
\hline Risnes et al [15] & $1989-2000$ & 18532 & $0.6 \%$ & Age, male gender, obesity, COPD, diabetes \\
\hline Crabtree et al [16] & $1996-2003$ & 4004 & $2.2 \%$ & Obesity, diabetes,"/>2 transfusion units \\
\hline Fowler et al [17] & $2002-2003$ & 331429 & NA & Obesity, diabetes, MI, urgent surgery \\
\hline Sjoegren et al [18] & $1999-2004$ & 4781 & $0.95 \%$ & Diabetes, obesity, low EF, renal failure \\
\hline Matros et al [19] & $1991-2006$ & 21000 & $1.35 \%$ & Prolonged CPB time \\
\hline De Feo et al [20] & $1979-2009$ & 22366 & $0.89 \%$ & NA \\
\hline Upton et al [21] & $1998-2003$ & 5176 & $1.2 \%$ & Diabetes, urgent surgery, low EF \\
\hline Sachithanandan et al [22] & $2001-2005$ & 4586 & $1.65 \%$ & $\begin{array}{l}\text { Diabetes, smoking, age, prolonged } \\
\text { ventilation }\end{array}$ \\
\hline
\end{tabular}

NA - not adrressed

BIMA - bilateral IMA harvesting

EF - ejection fraction

COPD - chronic obstructive pulmonary disease

$\mathrm{CHF}$ - congestive heart failure

$\mathrm{Ml}$ - myocardial infaction

Table 2. Analyses of incidence and risk factors of DSWI 


\section{Microbiology of DSWI and routes of infection}

Staphylococci, either S. aureus (SA) or coagulase-negative Staphylococcus (CONS) represent the most causative organism of DSWI, accounting for 60 to $80 \%$ of cases [34]. The proportion of individual strains of Staphylococcus and their methicillin-sensitivity varies between countries and institutions, reflecting their long-term hygienic and antibiotic policies [35]. Although surgical site infections are typically perceived to be an exogenous problem related to exposure to healthcare workers, the most causative pathogens are endogenous from patient's own skin or mucosal flora [36,37]. Nasal carriage of SA has been identified as a potential risk factor for DSWI [38], and genetically identical SA from nasal flora have been cultivated from sternotomy wounds [39]. Unlike SA which caused a more aggressive presentation, CONS infection accompanied with bacteremia as observed in 50-60\% of cases [34, 40] had a rather indolent course, clinically manifested later, and was more prone to recurrence [41, 42]. DSWI is diagnosed in $40-70 \%$ of patients post-discharge, thus post-discharge surveillance of up to 90 days is recommended [43]. Gram negative strains contribute less commonly in the pathogenesis of DSWI and mostly translocate from other host site infections, such as pneumonia, urinary or abdominal infections [34]. Finally, no significant difference in mortality was observed between DSWI infections caused by CoNS, when compared to SA, or Gram-negative pathogens [34]. Mekontso-Dessap et al suggested that DSWI caused by methicillin-resistant SA (MRSA) may have worse actuarial survival than sensitive strains (MSSA) in terms of 1 month, 1 -year, and 3-year survival $(60.0 \% \pm 12.6 \%, 52.5 \% \pm-3.4 \%$, and $26.3 \% \pm 19.7 \%$ versus $84.6 \%$ $\pm 7.1 \%, 79.0 \% \pm 8.6 \%$, and $79.0 \% \pm-8.65, \mathrm{p}=0.04)$, and a regression analysis revealed MRSA as an independent risk factor for overall mortality [44].

\section{Outcomes and cost of DSWI}

Unsurprisingly, DSWI negatively affected outcomes in cardiac surgery. Even with the adoption of modern treatment strategies, the reported in-hospital mortality for DSWI varies from 1.1 to $19 \%[6-9,11,16,45]$. Although the mortality rate is similar to data reported from the 1980s, it appears that implementation of negative pressure wound therapy (NPWT) may improve long-term survival of patients $[18,20,46]$. Regardless of treatment strategy, in-hospital stay of DSWI patients is at least two weeks longer compared to patients with an uncomplicated post-operative course $[6,10,11]$. DSWI-related morbidity was repeatedly reported in relation to prolonged mechanical ventilation, renal impairment, atrial and ventricular arrhythmias, cerebrovascular accidents, need for hemodynamic support, and healing-related complications $[20,47]$. The cause of death in the early post-operative period is mostly multiple organ failure initiated by sepsis or specific DSWI-related complications such as serious bleeding [6-8,16,18, 20]. Predictors of a poor outcome in DSWI patients that have been reported include length of intensive care unit (ICU) stay, late indication for surgical revision, bacteremia, hemodynamic instability, and prolonged mechanical ventilation [47,48]. Loop et al presented the worse survival data of DSWI in patients operated on during the 1980s in comparison with a standard CABG population within a 3-year follow-up after surgery [6]. Survival analyses published in 
the last decade consistently confirm long-term complications of patients with mid-, and long term survival rates who were successfully treated for DSWI (Table 3) $[8,11,12,14,15,18,22,46]$. Specific reasons for worsening of long-term survival are not yet clear. Risnes et al reported significantly higher cardiac-related deaths in the post-DSWI group (34.6 vs. $21.4 \%$, $\mathrm{p}<0.006$ ) and poorer survival for males ten years after surgery [15]. In contrast with this data, Sjoegren et al and Bailot et al showed unimpaired long-term survival of DSWI patients in comparison with patients who had uncomplicated surgery once NPWT was used $[18,46]$.

\begin{tabular}{|c|c|c|}
\hline Authors & $\begin{array}{l}\text { Patients' } \\
\text { enrollement }\end{array}$ & Survival analysis \\
\hline Loop FD et al [6] & 1985-1987 & $\begin{array}{l}\text { 3-year survival of } 62.5 \% \text { compared to } 69.0 \% \text { survival for patients with positive } \\
\text { cultures. Overall, the } 3 \text {-year survival was } 75 \% \text {, which is significantly below } \\
\text { previously reported 5-year and even } 10 \text {-year survival for isolated coronary bypass } \\
\text { patients }\end{array}$ \\
\hline Braxton et al [8] & 1992-1996 & $\begin{array}{l}\text { The adjusted survival rates at } 30 \text { days, } 1 \text { year, and } 4 \text { years were } 93 \%, 78 \% \text {, and } 65 \% \\
\text { among patients with mediastinitis and } 97 \%, 95 \% \text {, and } 89 \% \text { without mediastinitis, } \\
\text { respectively }(p<0.001 \text { ) }\end{array}$ \\
\hline $\begin{array}{l}\text { Hollenbeak et al } \\
\text { [11] }\end{array}$ & 1996-1998 & $\begin{array}{l}\text { DSWI patient had a } 1 \text {-year survival of } 78 \% \text { vs. } 99 \% \text { for non-infected CABG patients, } \\
p=0.0001\end{array}$ \\
\hline Filsouri et al [12] & 1998-2005 & $\begin{array}{l}\text { Survival rates at } 1,3, \text { and } 5 \text { years were } 72.4 \%, 64.3 \% \text { and } 55.8 \% \text { for patients with } \\
\text { DSWI compared with } 93.8 \%, 88 \% \text { and } 82 \% \text { for the control }(p<0.001)\end{array}$ \\
\hline $\begin{array}{l}\text { Toumpoulis et al } \\
\text { [14] }\end{array}$ & 1992-2002 & $\begin{array}{l}\text { Freedom from all cause mortality in patients in whom DSWI developed at } 1 \text { year, } 5 \\
\text { years, and } 10 \text { years after the operation was } 66.2 \%, 50.8 \% \text {, and } 40.6 \% \text { respectively, } \\
\text { compared with } 87.2 \%, 72.8 \% \text {, and } 54.3 \% \text { in patients without DSWI ( } p=0.0007 \text { ) }\end{array}$ \\
\hline Risnes et al [15] & $1989-2000$ & $\begin{array}{l}\text { The } 10 \text {-year, long-term survival for patients with mediastinitis was } 49.5 \% \text {, } \\
\text { compared with } 71.0 \% \text { in non-mediastinitis patients }(p<0.01)\end{array}$ \\
\hline Sjoegren et al [18] & ] 1999-2004 & $\begin{array}{l}\text { The actuarial survival at } 1 \text { year, } 3 \text { years, and } 5 \text { years was } 92.9 \%, 89.2 \% \text {, and } 89.2 \% \\
\text { for patients with mediastinitis and } 96.5 \%, 92.1 \% \text {, and } 86.9 \text { for those without } \\
\text { mediastinitis }(p=0.578)\end{array}$ \\
\hline $\begin{array}{l}\text { Sachithanandan } \\
\text { et al [22] }\end{array}$ & 2001-2005 & $\begin{array}{l}\text { Unadjusted freedom from all-cause mortality in patients with DSWI at } 1 \text { year, } 2 \\
\text { years, and } 3 \text { years after surgery was } 78.6 \pm 4.8 \%(95 \% \mathrm{Cl} 69-88.2 \%), 75.6 \pm 5.0 \% \\
(95 \% \mathrm{Cl} 65.6-85.6 \%) \text { and } 69.4 \pm 5.8 \%(95 \% \mathrm{Cl} 57.8-81 \%) \text { respectively compared } \\
\text { with } 92.8 \pm-0.4 \%(95 \% \mathrm{Cl} 92.4-93.2 \%), 90.7 \pm 0.5 \%(95 \% \mathrm{Cl} 90.2-91.2 \%) \text { and } \\
87.7 \pm 0.6 \%(95 \% \mathrm{Cl} 87.1-88.3 \%) \text { for patients without DSWI }(p<0.001)\end{array}$ \\
\hline Bailot et [46] & 1992-2007 & $\begin{array}{l}\text { Survival in patients with DSWI showed freedom from all-cause mortality at 1, } 5 \text { and } \\
10 \text { years to be, respectively, } 91.8 \%, 80.4 \% \text { and } 61.3 \% \text { compared with } 94.0 \%, 85.5 \% \\
\text { and } 70.2 \% \text {, respectively, for patients }(p=0.01) \text {. Adjusted survival for patients with } \\
\text { DSWI treated with NPWT was } 92.8 \%, 89.8 \% \text { and } 88.0 \% \text {, respectively, at } 1,2 \text { and } 3 \\
\text { years, compared with } 83.0 \%, 76.4 \% \text { and } 61.3 \% \text {, respectively, for patients with } \\
\text { DSWI treated conventionaly }(p=0.02)\end{array}$ \\
\hline
\end{tabular}

Table 3. Analyses of compared mid-term and long-term survival of patients with DSWI with non-DSWI patients 
Patients who develop DSWI are 2.5 to 3 times more expensive to manage compared with patients who have an uncomplicated post-operative course $[6,11]$. The first calculation of cost originated from the Loop et al paper, published in the late 1980 's, and found a 2.8 times increase in cost [6]. Patients who died of DSWI consequences consumed 60,500 USD more, making the total cost of these patients approximately 80,000 USD compared with 11,000 USD an uncomplicated CABG patient cost, as showed by Hollenbeak et al [11]. Recent data from Germany showed a doubling in cost $(36,261$ vs. 13,356 EUR, p<0.001) for DSWI patients [49], while Ennker et al calculated a 9,000 EUR increase in cost on average for any DSWI case [50]. The majority of the increased cost is spent on repeat surgical and ICU service, and extension of inhospital stay $[11,51,52]$. In looking for cost-effectiveness of treatment strategies, NPWT does not seem to be a more expensive treatment in comparison with the conventional therapy for DSWI, as calculated in the Swedish healthcare system by Mokhari et al [52]. Atkins et al reported lower NPWT costs than Medicare charges for conventional therapy (152,000 vs. 300,000 USD) of DSWI [53].

\section{Strategies preventing DSWI}

As mentioned previously, diabetes mellitus is a strong independent risk factor for development of DSWI, and concomitant obesity doubles the risk of further infection [24]. Unfortunately, both risk factors are difficult to modify. Zerr et al showed that a continuous insulin infusion started immediately after surgery to maintain a serum glucose level of $150-200 \mathrm{mg} / \mathrm{dl}$ (8-11 $\mathrm{mmol} / \mathrm{l})$ led to a significant decrease in the incidence of DSWI in diabetics $(2.4 \%$ to $1.5 \%$, $\mathrm{p}<0.02)$ compared with subcutaneously administered insulin [54]. A tight glycemic control protocol appears beneficial from the Portland group experience, nevertheless, decreasing serum glucose below $100 \mathrm{mg} / \mathrm{dl}(6 \mathrm{mmol} / \mathrm{l})$ did not bring any additional impact on DSWI rate, and was associated with a higher risk of stroke or death [55].

It has been demonstrated many times that antibiotic prophylaxis effectively prevents sternal wound infection [56]. As Staphylococcal stains are a major causative pathogen, beta-lactam antiobiotics are recommended for prophylaxis, particularly first or second generation cephalosporins [57]. The use of glycopeptides, which are highly effective against MRSA, has not been linked with a reduction in sternal wound infection rates compared to standard prophylaxis, with one study suggesting higher SSI's rate (3.7 vs. $1.3 \%, \mathrm{p}<0.05)$ when vancomycin prophylaxis was chosen [58]. Local application of a gentamicin soaked-collagen sponge between the sternal lamella was suggested to reduce all SWI's, particularly DSWI. Friberg et al reported a significant reduction in SWI's (3.7 vs. 9\%, p<0.001), and also DSWI (1.5 vs. 3.3\%, $\mathrm{p}<0.003$ ) [59,60], however, further randomized controlled trials and meta-analyses did not confirm a benefit of using a gentamicin sponge for DSWI prevention as well as a recently published meta-analysis [61,62]. Although SA caused DSWI might be reduced by locally applied gentamicin, primarily gentamicin-resistant strains such a CONS may overgrow [62].

Another prophylactic issue is patient decontamination before surgery. As Staphylococci colonization is seen in a majority of DSWI, skin and nasopharyngeal decontamination became 
popular $[38,39]$. The use of chlorhexidine for skin care before surgery showed a significant reduction in the microbial count including SA [63]. In comparison to general surgery where reduction of SSI's due to skin decontamination was confirmed [64], data for cardiac surgery is lacking, nevertheless, protocols involving chlorhexidine or a different skin cleanser are already widely accepted. Locally applied ointment containing mupirocin is 80 to $90 \%$ effective in eradicating all types of SA from the nasopharyngeal mucosa [65]. Cimochowski et al reported about the efficacy of this practice on reducing DSWI rates from $2.7 \%$ to $0.9 \%$ [66]. A randomized controlled trial published by Konvalinka et al did not confirm a reduced DSWI rate from the use of nasal mupirocin ointment (0.8 vs. 0.8\%) [67].

The surgical technique in performing median sternotomy and its closure certainly influences the risk of DSWI. Careful handling of skin and pre-sternal soft tissue, mid-lined sternal incision and avoidance of bone wax are essential, in addition to keeping scrub protocol, checking for glove injury, changing gloves after sternotomy and after sternal wiring, and leaving the closed wound primarily covered for at least 48 hours [68].

It has been proposed that the method of IMA harvesting affects the incidence of DSWI, particularly when both IMA (BIMA's) are demanded for revascularization $[7,8,10,27,28]$. A recent meta-analysis published by Saso et al showed a reduced risk of SWI's once IMA or BIMA's were harvested in a skeletonized fashion compared with a pedicled graft. The risk was reduced both in the non-diabetic (2.96\% vs. $11.7 \%)$ and diabetic populations ( $2.4 \%$ vs. $14.2 \%)$ [69]. Besides harvesting methods of BIMA's in diabetics, as was mentioned above, tight longterm glycemic control influenced the risk of DSWI. A hemoglobin A1c (HbA1c) $\geq 7 \%$ had a higher incidence of DSWI compared with patients who had a $\mathrm{HbA} 1 \mathrm{c}<7 \%$ (5.0\% vs. $1.4 \%, \mathrm{P}=$ 0.014). A $31 \%$ increased risk of DSWI (OR $=1.31,95 \%$ CI 1.16-1.49, $\mathrm{P}<0.001)$ was seen by Halkos et al [26]. Even through diabetic patients may have a comparable risk of developing DSWI when IMA in skeletonized fashion is taken down, the BIMA's harvesting need is to be considered carefully because additional risk factors such an obesity and COPD are commonly presented in this cohort $[24,70]$.

The crucial point in preventing DSWI is achievement of stable sternal approximation. Standard sternal wire cerclage, if performed well, is fast, easy and effective [71]. Facing poor sternal quality, sternal fracture, or increased traction forces in obese or COPD patients, some modifications of this technique were proposed. Parasternal wire reinforcement, described originally by Robicsek and modified by Sharma, proved to reduce the risk of sternal wound complications [72,73]. Friberg et al reported that the use of more than 6 or 7 simple wires may also reduce DSWI rates $(0.4 \%$ vs. $4.2 \%, \mathrm{p}=0.001)$ [74]. Recently, a large multicenter prospective study conducted by Schimmer et al comparing the Robicsek technique with standard cerclage failed to reduce the risk of SWI and sternal dehiscence [75]. Primary plating, mirroring the experience in maxillofacial surgery, was proposed for patients at high risk of sternal non-union [76]. Plates could be anchored only into the sternal bone (SternaLock system ${ }^{\mathrm{TM}}$,Biomet Microfixation Inc, Jacksonville, US) or into the ribs (Titanium Sternal Fixation system ${ }^{\mathrm{TM}}$, Syntes, Switzeland). Raman et al reported better chest bone healing after primary plating than rewiring at 6-month follow up (70 vs. 24\%, p=0.003) and lower pain scores, with no difference in SWI rates [77]. Others systems are used for sternal approximation including, thermoreactive nitinol clips 
(Flexigrip $^{\mathrm{TM}}$, Praesidia SRL, Bologna, Italy), titanium locked staples (Sternal Talon ${ }^{\mathrm{TM}}$, KLS Martin Group, US), and Poly-Ether-Ether-Ketone tapes (Sternal ZipFix system ${ }^{\mathrm{TM}}$, Syntes, Switzeland), all designed for parasteral fixation. Negri et al reported a significant reduction of mechanical dehiscence ( $2.8 \%$ vs. $0.2 \%, \mathrm{p}=0.002)$, but the same risk of DSWI $(1.2 \%$ vs. $2.4 \%)$ when thermoactive clips were compared with standard wire cerclage [78]. Snyder et al reported 5 years of experience with the SternaLock system ${ }^{\mathrm{TM}}$ for primary plating in high risk patients. Superiority of plate over wires was seen in the incidence of early presentation $(<30$ days) of SWI $(0 \%$ vs. $12 \%, \mathrm{p}<0.06)$ and shorter in-hospital stay ( 7 vs. 8 days, $\mathrm{p}=0.02)$ [79]. A pilot study published by Bennett-Guerrero et al showed insignificantly higher spirometry volume in the SternalTalon ${ }^{\mathrm{TM}}$ arm $(67 \% \pm 32 \%)$ versus the wire arm $(58 \% \pm 24 \%)$. Use of the Talon was associated with decreased use of opiates ( $21.3 \pm 11.8$ vs. $25.4 \pm 21.6 \mathrm{mg}, \mathrm{P}=0.44)$, duration of mechanical ventilation ( 0.5 vs. 1.0 days, $P=0.24)$ and hospital length of stay $(4.5 \pm$ 3.2 vs. $5.3 \pm 4.0$ days, $\mathrm{P}=0.40)[80]$.

A promising method to reduce SSI seems to be the application of NPWT on surgically closed sternal wounds. A commercially available system (Prevena ${ }^{\circledR}$ Incision Management System, $\mathrm{KCI}$, St. Antonio, USA) is used, with skin preservation through a semipermeable membrane that has contact with foam, and one proposal pump system with reservoir is added [81]. Limited clinical experience has shown a decreased risk of wound hematoma, seroma and SSI [82]. Other positive effects from wound application of NPWT might include promotion of microvascular flow and decreased tissue edema and myofibroblast activation [83]. Colli and Atkins et al reported no wound healing complications in patients at high risk for sternal wound infections after cardiac surgery, but both studies were retrospective and done on smaller cohort of patients, 10 and 57, respectively [84,85].

\section{Treatment strategies for DSWI}

Even though treatment of DSWI has considerably evolved, a generally accepted treatment strategy remains controversial. Robicsek postulated three valid principles addressing this issue: first, that the infectious process should be brought under control within the shortest possible time, secondly, that adequate debridement and drainage of the infected area should occur, and third that sternal stability should be assured [86]. Until the 1960s, patients suffering from DSWI were treated conservatively with antibiotic therapy, limited drainage, or exposure of the sternotomy wound until closure with granulation tissue occurred [87]. Mortality rates then reached over $50 \%$ and survivors' quality of life was limited due to significant morbidity [87]. In 1964, Shumacker and Mandelbaum reported their experience with single-stage technique of wound debridement, primary sternal re-wiring and continuous antibiotic irrigation [88]. Their original method was consequently modified in terms of the type of antibiotic or antiseptic solution used including its amount, or the setting of indwelling drains for irrigation and suction [89-90]. Closed chest drainage became widely used with reported mortality from DSWI ranging from $4.8 \%$ to $28 \%$, with an associated risk of primary therapy failure ranging from $12.5 \%$ to $48 \%$ [89,90-92]. Lee et al proposed in 1976 the use of an omental flap for covering infected sternotomy wounds [93]. Vital greater omentum was turned into the 
chest cavity following sternal debridement. It was suggested that well-vascularized omentum fulfills dead spaces, ensures high antibiotic levels, and yielded angiogenic and absorptive capacity $[13,93]$. Jurkiewicz et al first reported the use of muscle flaps, preferably the pectoralis flap, and radical sternal debridement in the treatment of DSWI in 1980 [94]. Consequently, 20years of experience in the Emory group with 409 patients showed $8.1 \%$ in-hospital mortality and $5.1 \%$ primary therapy failure. $87.1 \%$ of procedures were done in single-stage fashion; the pectoralis major was used in $76.6 \%$, rectus abdominis in $19.4 \%$, and omentum in $2.2 \%$ [95]. This approach has received many modifications regarding the timing of wound closure, choice of flap, and type of advancement, with reported mortality ranging from $0 \%$ to $19 \%$ [96,97]. Comparing the omental to the pectoralis flap, Milano et al reported that the omental flap had lower mortality $(4.8 \%$ vs. $10.5 \%, \mathrm{p}<0.05)$, early wound related complications $(9.5 \%$ vs. $27.7 \%, \mathrm{p}<0.001)$, and in-hospital stay (10.7 vs. $18.8 \%$, p<0.05) [98]. El Oakley and Wright suggested classification of DSWI based on the time of presentation, presence of risk factors such as obesity, diabetes or immunosuppressive therapy, and number of failed therapeutic attempts in 1996 (Table 3) [99]. The identification of five subtypes of DSWI seemed to be a relevant tool for choice of therapeutic method and patient prognosis. Adjusted to the El Oakley and Wright classification, closed chest irrigation has comparable mortality data for type I and II DSWI compared with radical sternal resection and concomitant flap, but with lower flaprelated associated morbidity [100-102]. Ringelman et al noted that at 48 month follow-up, 51\% of patients had pain or discomfort, $44 \%$ had numbness, $42 \%$ complained of sternal instability, and $33 \%$ claimed to have shoulder weakness, when pectoral flap was used for reconstruction [103]. Closed chest irrigation carries a higher rate of therapy failure when used for type III, and particularly type IV and V El Oakley and Wright classification [104-107]. Thus, these patients might have benefit from more radical sternal debridement and employment of well-vascularized tissue to replenish residual defects. Flap-related morbidity may be addressed with less invasive techniques such as a laparoscopic greater omentum harvesting [108]. Atkins et al recently reported on the influence of sternal repair choice (pectoral, omental flap, or secondary closure) on long-term survival [109].

There is limited data evaluating hyperbaric oxygen (HBO) therapy in the treatment of SWI, despite theoretical advantages, availability of HTO close to the cardiac surgical unit impedes its routine use [110]. Siondalski et al reported successful healing of 55 DSWI patients with no mortality, nevertheless therapy required 20-40 HBO sessions after surgical revision. HTO was taken as an adjunct therapy to perform radical debridement and muscle flap [111].

\begin{tabular}{ll}
\hline Class & Description of DSWI \\
\hline Type I & Mediastinitis presenting within 2 weeks after operation in the absence of risk factors \\
\hline Type II & Mediastinitis presenting at 2 to 6 weeks after operation in the absence of risk factors \\
\hline Type IIIA & Mediastinitis type I in the presence of one or more risk factors \\
\hline Type IIIB & Mediastinitis type II in the presence of one or more risk factors \\
\hline Type IVA & Mediastinitis type I, II, or III after one failed therapeutic trial \\
\hline
\end{tabular}




\begin{tabular}{ll}
\hline Class & Description of DSWI \\
\hline Type IVB & Mediastinitis type I, II, or III after more than one failed therapeutic trial \\
\hline Type V & Mediastinitis presenting for the first time more than 6 weeks after operation \\
\hline
\end{tabular}

Accepted risk factors: diabetes, obesity, immunosupressive therapy intake

Table 4. El Oakley and Wright classification of DSWI (modified from El Oakley et[99])

In 1997, Obdeijin et al described the first application of NPWT for treatment of DSWI in 3 consecutive patients [112]. They found that physical therapy contracted the wound, provided sufficient chest stability, and allowed patients to be extubated. Catarino et al reported the first retrospective comparison between NPWT and closed chest irrigation in 2000. In comparing 9 versus 10 patients, they found superiority of NPWT in length of in-hospital stay ( $15 \mathrm{vs} .40 .5$ days, $\mathrm{p}=0.02$ ) and therapy failure (0 vs. 5, p=0.03) [113]. Furthermore, Gustafsson et al and Fleck et al, from the two most active European centers (Lund and Vienna), reported similar in-hospital and 30 -day or 90 -day mortality of DSWI patients, with $60 \%$ of all cases having class III according to ElOakley and Wright $[114,115]$. Consequently, the Lund group reported survival data from 1,3, and5yearfollow-up which showed comparablesurvival $(92.9 \%, 89 \%, 89 \%)$ with patients without DSWI after CABG $(96 \%, 92 \%, 86 \%)$ and showed potential survival benefit of NPWT therapy unlike data known from conventional therapy [18]. Recently published data from a larger group of patients showed $1.1-5.4 \%$ mortality at 30 days and $8-15 \% 1$ year mortality with a 2 to $6 \%$ risk of primary therapy failure [116-119]. The mean length of application of NPWT was 8 to 14 days with a mean number of 4 to 6 dressing changes [116-119]. The amount of dressing used by centers has only minor variability in first-line application protocol, with the only differences reported being the materials used for interface dressing and the timing of wound closure [116-119]. It was suggested that low C-reactive protein level $(<50 \mathrm{mg} / \mathrm{l})$ might be a good indicator for timing of wound closure[120].Since theintroduction of NPWT, its comparison with conventional therapy, closed chest irrigation or sternal resection and flap have been studied. So far, we have data only from retrospective comparative studies, with the compared arms being heterogeneous in number of patients, time periods and type of DSWI based on El Oakley classification. It was suggested that NPWT positively influenced the risk of primary therapy failure and survival of patients at short and long-term follow-up [18,46,121-138]. Outcomes of NPWT are DSWI causative pathogen independent, even comparing therapeutic response to MRSA and MSSA causedDSWI[139].From multivariableanalyses, obesity, renalfailureand sepsiswerecalculated as independent risk factors of NPWT failure $[128,129]$. Results of comparative studies and published meta-analyses are shown in Table 5.

\begin{tabular}{|c|c|c|c|c|}
\hline Authors & Follow-up & $\begin{array}{l}\text { Patients } \\
\text { 'cohort }\end{array}$ & Endpoints & Results \\
\hline $\begin{array}{l}\text { Catarino et al } \\
{[113]}\end{array}$ & Retrospective & $\begin{array}{l}11 \text { pts NPWT } \\
\text { vs. } 9 \text { pts closed } \\
\text { irrigation }\end{array}$ & $\begin{array}{l}\text { In-hospital stay, } \\
\text { therapy failure }\end{array}$ & $\begin{array}{l}\text { yNPWT linked with shorter in-hospital stay ( } 15 \\
\text { vs. } 40.5 \text { days, } p=0.02 \text { ) and lower therapy } \\
\text { failure ( } 0 \text { vs. } 5 \%, p=0.03 \text { ) than closed irrigation }\end{array}$ \\
\hline
\end{tabular}




\begin{tabular}{|c|c|c|c|c|}
\hline Authors & Follow-up & $\begin{array}{l}\text { Patients } \\
\text { 'cohort }\end{array}$ & Endpoints & Results \\
\hline Berg et al [121] & ]Retrospective & $\begin{array}{l}31 \text { pts NPWT } \\
\text { vs. } 29 \text { pts } \\
\text { closed } \\
\text { irrigation }\end{array}$ & $\begin{array}{l}\text { Primary therapy failure, } \\
\text { in-hospital stay and } \\
\text { mortality }\end{array}$ & $\begin{array}{l}\text { NPWT group had a lower risk of therapy } \\
\text { failure ( } 52 \text { vs. } 16 \%, p<0.05 \text { ) and in-hospital } \\
\text { stay ( } 22 \text { vs. } 26 \text { days, } p<0.05 \text { ), with comparable } \\
\text { in-hospital mortality ( } 6,9 \text { vs. } 6,6 \% \text {, NS) to } \\
\text { closed irrigation }\end{array}$ \\
\hline $\begin{array}{l}\text { Doss et al } \\
{[122]}\end{array}$ & Retrospective & $\begin{array}{l}22 \text { pts NPWT } \\
\text { vs. } 22 \text { closed } \\
\text { irrigation }\end{array}$ & $\begin{array}{l}\text { Primary therapy failure, } \\
\text { in-hospital stay and } \\
\text { mortality }\end{array}$ & $\begin{array}{l}\text { NPWT group had shorter overall length of } \\
\text { therapy }(17.2 \pm 5.8 \text { vs. } 22.9 \pm 10.8 \text { days, } p=0.01 \text { ) } \\
\text { and in-hospital stay ( } 27.9 \pm 6.6 \text { vs. } 33.0 \pm 11.0 \\
\text { dnů, } p=0.03 \text { ), with comparable mortality ( } 5 \text { vs. } \\
5 \%, N S \text { ) to closed irrigation }\end{array}$ \\
\hline $\begin{array}{l}\text { Song et al } \\
{[123]}\end{array}$ & Retrospective & $\begin{array}{l}17 \text { pts NPWT } \\
\text { vs. } 18 \text { pts open } \\
\text { packing }\end{array}$ & $\begin{array}{l}\text { Primary therapy failure, } \\
\text { number of dressing } \\
\text { changes, in-hospital } \\
\text { stay and mortality }\end{array}$ & $\begin{array}{l}\text { NPWT associated with shorter length of } \\
\text { therapy ( } 6.2 \text { vs. } 8.5 \text { days, } p<0,05) \text {, lower } \\
\text { number of dresssing changes ( } 3 \pm 2.5 \text { vs. } \\
17 \pm 8.6, p<0.01) \text {, and comparable in-hospital } \\
\text { mortality ( } 11 \text { vs. } 6 \% \text {, NS) }\end{array}$ \\
\hline $\begin{array}{l}\text { Luckraz et al } \\
{[124]}\end{array}$ & Retrospective & $\begin{array}{l}27 \text { pts NPWT } \\
\text { vs. } 13 \text { pts } \\
\text { closed } \\
\text { irrigation }\end{array}$ & $\begin{array}{l}\text { Primary therapy failure, } \\
\text { in-hospital mortality, } \\
\text { and cost of therapy }\end{array}$ & $\begin{array}{l}\text { NPWT linked with lower therapeutic failure } \\
\text { rate ( } 15 \text { vs. } 30.7 \%, p<0.05) \text {, in-hospital } \\
\text { mortality }(7.5 \% \text { vs. } 18.5 \%, p<0.05 \text { ) and overall } \\
\text { cost of therapy ( } 16400 \text { vs. } 20000 \text { USD) } \\
\text { compared with closed irrigation }\end{array}$ \\
\hline $\begin{array}{l}\text { Fuchs et al } \\
{[125]}\end{array}$ & Retrospective & $\begin{array}{l}35 \text { pts NPWT } \\
\text { vs. } 33 \text { pts open } \\
\text { packing }\end{array}$ & $\begin{array}{l}\text { Lenght to achieve } \\
\text { sterile woud, length of } \\
\text { therapy, in-hospital } \\
\text { stay, and 1-year survival }\end{array}$ & $\begin{array}{l}\text { NPWT led to faster bacterial decontamination } \\
\text { of wounds ( } 16 \text { vs. } 26 \text { days, } p<0.01 \text { ), shorter } \\
\text { length of therapy ( } 21 \text { vs. } 28 \text { days, } p<0.01 \text { ) and } \\
\text { l in-hospital stay ( } 25 \text { vs. } 34 \text { days, } p<0.01 \text { ) and } \\
\text { better } 1 \text {-year survival ( } 97.1 \text { vs. } 74.7 \%, p<0,05 \text { ) } \\
\text { compared with open packing }\end{array}$ \\
\hline $\begin{array}{l}\text { Sjoegren at el } \\
{[126]}\end{array}$ & Retrospective & $\begin{array}{l}61 \text { pts NPWT } \\
\text { vs. } 40 \text { closed } \\
\text { irrigation/ } \\
\text { open packing }\end{array}$ & $\begin{array}{l}\text { Therapy failure, } 1 \text { - and } \\
5 \text {-year mortality }\end{array}$ & $\begin{array}{l}\text { NPWT had lower risk of therapy failure ( } 0 \text { vs. } \\
15 \%, p<0.01 \text { ), } 90 \text { day mortality ( } 0 \text { vs. } 15 \% \text {, } \\
p<0,01 \text { ), and } 1 \text { - and } 5 \text {-year survival ( } 93 \text { vs. } \\
82 \%, 83 \text { vs. } 59 \%, p<0.05 \text { ) against conventional } \\
\text { therapy }\end{array}$ \\
\hline $\begin{array}{l}\text { Immer et al } \\
\text { [127] }\end{array}$ & Retrospective & $\begin{array}{l}38 \text { pts NPWT } \\
\text { vs. } 17 \\
\text { sternectomy } \\
\text { and flap }\end{array}$ & $\begin{array}{l}\text { In-hospital stay and in- } \\
\text { hospital mortality, } \\
\text { quality of life }\end{array}$ & $\begin{array}{l}\text { NPWT led to shorter in-hospital stay } \\
(51.5 \pm 20.8 \text { vs. } 70.7 \pm 28.8 \text { dnů, } p<0.05) \text {, non- } \\
\text { significantly lower in-hospital mortality ( } 5.3 \text { vs } \\
11.8, \text { NS) and better quality of life based on } \\
\text { questionnaire SF-36 compared with } \\
\text { sternectomy and flap }\end{array}$ \\
\hline
\end{tabular}




\begin{tabular}{|c|c|c|c|c|}
\hline Authors & Follow-up & $\begin{array}{l}\text { Patients } \\
\text { 'cohort }\end{array}$ & Endpoints & Results \\
\hline Segers [128] & Retrospective & $\begin{array}{l}29 \text { pts NPWT } \\
\text { vs. } 34 \text { pts } \\
\text { closed } \\
\text { irrigation }\end{array}$ & $\begin{array}{l}\text { Therapy failure, in- } \\
\text { hospital, and 1-year } \\
\text { mortality }\end{array}$ & $\begin{array}{l}\text { NPWT decreased primary therapy failure ( } 27.6 \\
\text { vs. } 58.9 \%, \mathrm{p}<0.05) \text {, with comparable } 30 \text { day } \\
(3,5 \text { vs. } 2,9 \%, \text { NS)and } 1 \text {-year mortality ( } 31.0 \text { vs. } \\
23.5 \%, N S) \text { to closed irrigation }\end{array}$ \\
\hline$[46$ & $\begin{array}{l}\text { Retrospektive } \\
\text { conventional } \\
\text { and prospective } \\
\text { for NPWT }\end{array}$ & $\begin{array}{l}125 \text { pts NPWT } \\
\text { vs. } 24 \text { pts. } \\
\text { open packing }\end{array}$ & $\begin{array}{l}\text { In-hospital mortality } \\
\text { and 1-,5-, and } 10 \text { years } \\
\text { survival }\end{array}$ & $\begin{array}{l}\text { Lower mortality in NPWT group ( } 4.8 \text { vs. } 14.1 \% \text {, } \\
\text { p=0.01), but insignificantly better } 1,5 \text {, and } 10 \\
\text { year survival( } 92.8 \text { vs. } 83.0 \%, 89.8 \text { vs. } 76.4 \% \text {, } \\
88.0 \text { vs. } 61.3 \% \text {, NS) }\end{array}$ \\
\hline $\begin{array}{l}\text { Petzina et al } \\
\text { [129] }\end{array}$ & Retrospective & $\begin{array}{l}69 \text { pts NPWT } \\
\text { vs. } 49 \text { closed } \\
\text { irrigation }\end{array}$ & $\begin{array}{l}\text { Primary therapy failure, } \\
\text { in-hospital stay and } \\
\text { mortality }\end{array}$ & $\begin{array}{l}\text { NPWT associated with lower therapeutic } \\
\text { failure ( } 2.9 \% \text { vs. } 18.3 \% \mathrm{p}<0.05) \text { and in-hospital } \\
\text { mortality ( } 5.8 \% \text { vs. } 24.5 \% \mathrm{p}<0.05) \text {, but } \\
\text { comparable in-hospital stay ( } 38 \text { vs. } 41 \text { days, } \\
\text { NS) with closed irrigation }\end{array}$ \\
\hline $\begin{array}{l}\text { Simek et al } \\
{[130]}\end{array}$ & $\begin{array}{l}\text { Retrospective } \\
\text { for conventional } \\
\text { and propective } \\
\text { pro NPWT }\end{array}$ & $\begin{array}{l}38 \text { pts } \\
\text { I withNPWT vs. } \\
28 \text { pts closed } \\
\text { irrigation }\end{array}$ & $\begin{array}{l}\text { Primary therapy failure, } \\
\text { in-hospital stay, in- } \\
\text { hospital, and } 1 \text { year } \\
\text { mortality }\end{array}$ & $\begin{array}{l}\text { NPWT had lower failure of primary therapy } \\
\text { ( } 5.8 \text { vs. } 39.2 \%, p<0.05), \text { ICU stay }(209.6 \pm 33.3 \\
\text { vs. } 516.1 \pm 449.5 \text { hours, } p<0.01 \text { ), and in-hospital } \\
\text { ( } 5.8 \text { vs. } 21.4 \%, p<0.05 \text { ) and } 1 \text {-year mortality } \\
\text { ( } 14.7 \text { vs } 39.2 \%, p<0.05 \text { ), but comparable in- } \\
\text { hospital stay }(40.2 \pm 16.3 \text { vs. } 48.8 \pm 29.2 \text {, NS) } \\
\text { with closed irrigation. }\end{array}$ \\
\hline
\end{tabular}

De Feo et al Retrospective 74 pts NPWT Primary therapy failure, NPWT group with lower risk of therapy failure [131] vs. 83 pts in-hospital stay and $\quad(1.4$ vs. $16.9 \%, p<0.001)$, shorter in-hospital closed mortality stay $(23.3 \pm 9$ vs. $3.0 .5 \pm 3, p<0,05)$, and lower inirrigation hospital mortality ( 1.4 vs. $3,6 \%, p<0, .05)$ compared with closed irrigation

\begin{tabular}{|c|c|c|c|c|}
\hline $\begin{array}{l}\text { Assman et al } \\
\text { [132] }\end{array}$ & Retrospective & $\begin{array}{l}82 \text { pts NPWT } \\
\text { vs. } 38 \text { closed } \\
\text { irrigation }\end{array}$ & $\begin{array}{l}\text { In-hospital stay and } \\
\text { mortality }\end{array}$ & $\begin{array}{l}\text { NPWT patients had shorter in-hospital stay } \\
(45.6 \pm 18.5 \text { vs. } 55.2 \pm 23.6 \text { dnů, } p<0.05) \text {, and } \\
\text { lower in-hospital mortality ( } 14.6 \text { vs. } 32.4 \% \text {, } \\
p<0.05)\end{array}$ \\
\hline
\end{tabular}

Vos et al [133] Retrospective 89 pts NPWT In-ICU and hospital stay NPWT led to shorter ICU stay (6.8 \pm 14.4 vs. vs. 24 open and mortality $\quad 18.5 \pm 21.0$ dnů, $p<0.01)$, in-hospital stay packing (74.4 $\quad$ (61.2 vs. $69.1 \pm 62.7$ days, $p<0.01)$, and lower in-hospital mortality (12.4 vs. $41.7 \%$, $\mathrm{p}<0.01)$

Deniz et al Retrospective 47 pts NPWT Primary therapy failure, NPWT had insignificantly lower rate of primary [134] vs. 43 pts in-hospital stay and 1-, therapy failure (2.1\% vs. $4.7 \%, \mathrm{NS})$ and shorter closed $\quad 3$ years mortality in-hospital stay ( $18 \pm 9$ vs. $24 \pm 10$ days, NS), 90 irrigation days mortality significantly lower (8.5 vs. $23.2 \%, p<0.05$ ) and better 1 -, and 3 -year 


\begin{tabular}{|c|c|c|c|c|}
\hline Authors & Follow-up & $\begin{array}{l}\text { Patients } \\
\text { 'cohort }\end{array}$ & Endpoints & Results \\
\hline & & & & $\begin{array}{l}\text { survival ( } 91.5 \% \text { vs. } 76.7 \%, p<0,05,87.2 \text { vs. } \\
69.8 \%, P<0.05)\end{array}$ \\
\hline $\begin{array}{l}\text { Fleck et al } \\
\text { [135] }\end{array}$ & Retrospective & $\begin{array}{l}326 \text { pts NPWT } \\
\text { vs. } 198 \text { closed } \\
\text { irrigation/ } \\
\text { open packing }\end{array}$ & $\begin{array}{l}\text { Primary therapy failure, } \\
\text { in-hospital mortality }\end{array}$ & $\begin{array}{l}\text { NPWT was associated with lower primary } \\
\text { therapy failure ( } 8.5 \% \text { vs. } 34 \% p<0.001) \text {, and } \\
\text { in-hospital mortality ( } 3.6 \% \text { vs. } 10 \%, p<0.05)\end{array}$ \\
\hline $\begin{array}{l}\text { Sjoegren at el } \\
{[18]}\end{array}$ & Meta-analysis & $\begin{array}{l}12 \text { papers } \\
\text { focused on } \\
\text { comparison of } \\
\text { NPWT with } \\
\text { conventional } \\
\text { therapy }\end{array}$ & $\begin{array}{l}\text { Primary therapy failure, } \\
\text { in-hospital stay and } \\
\text { mortality }\end{array}$ & $\begin{array}{l}\text { NPWT associated with lower primary therapy } \\
\text { failure, shorter in-hospital stay, and lower in- } \\
\text { hospital and 1-year mortality }\end{array}$ \\
\hline Raja et al [136] & ] Meta-analysis & $\begin{array}{l}13 \text { papers } \\
\text { focused on } \\
\text { comparison of } \\
\text { NPWT with } \\
\text { conventional } \\
\text { therapy }\end{array}$ & $\begin{array}{l}\text { Primary therapy failure, } \\
\text { in-hospital stay and } \\
\text { mortality }\end{array}$ & $\begin{array}{l}\text { NPWT seemed to be effective at high-risk } \\
\text { DSWI patients, but weak evidence for routine } \\
\text { first-line application in DSWI }\end{array}$ \\
\hline $\begin{array}{l}\text { Schimmer et al } \\
\text { [137] }\end{array}$ & Meta-analysis & $\begin{array}{l}15 \text { papers } \\
\text { focused on } \\
\text { comparison of } \\
\text { NPWT with } \\
\text { conventional } \\
\text { therapy }\end{array}$ & $\begin{array}{l}\text { Primary therapy failure, } \\
\text { in-hospital stay and } \\
\text { mortality, evaluation of } \\
\text { German hearts centers } \\
\text { protocols }\end{array}$ & $\begin{array}{l}\text { NPWT is associated with lower therapeutic } \\
\text { failure, and in-hospital mortality. Routinely } \\
\text { applied as first-line treatment in 35\% of } \\
\text { German heart centers }\end{array}$ \\
\hline $\begin{array}{l}\text { Damiani G et } \\
\text { al [138] }\end{array}$ & Meta-analysis & $\begin{array}{l}6 \text { papers } \\
\text { focused on } \\
\text { comparison of } \\
\text { NPWT with } \\
\text { conventional } \\
\text { therapy and } \\
\text { chest } \\
\text { reconstruction } \\
\text { options }\end{array}$ & $\begin{array}{l}\text { Primary therapy failure, } \\
\text { in-hospital stay and } \\
\text { mortality }\end{array}$ & $\begin{array}{l}\text { NPWT prone to have shorter in-hospital stay } \\
\text { and lower mortality }\end{array}$ \\
\hline
\end{tabular}

Table 5. Analyses and Meta-analyse of comparison NPWT with conventional therapy

Addressing specific complications of DSWI, it is seen that NPWT does not increase the risk of late infection recurrence. Reported rates of chronic fistulas after conventional therapy and NPWT were comparable between 8-12\% [18,130,134,140,41], and long-term survival of these patients is negatively affected $[140,142]$. CONS was identified as a pathogen with a higher risk 
of recurrence; its low virulence, ability to create biofilm on metallic materials and inherent low sensitivity against prophylactically administrated antibiotics limit its eradication $[41,143]$.

With the rise in use of NPWT came an increased number of reported serious bleeding complications $[144,145]$. The risk of heart injury, particularly the right ventricle, bypass grafts or great vessels is well known from conventionally treated patients. Infectious erosion, displacement of heart structures towards sternal margins, or tractions of fibrosis adhesion were identified as potential mechanism of injury [146]. The incidence of these complications by conventional therapy was found to be between 2-14.8\% [147-149], with data from a larger group of NPWT treated patients showing 2 to $5 \%$, thus NPWT does not seem to increase the incidence of serious complications [116,118,127,130,146,150]. Mortality from these complications varies between 25 to $70 \%$, with emergency surgery as well as proper covering of mediastinal structures with interface dressing being crucial for management [146-148,150]. Several layers of paraffin gauze or silicone mesh are usually put below sternal margins on the heart and grafts. Development towards more suitable material, particularly rigid barrier for mediastinal protection is in progress, including mediastinal protection and preserved drainage ability of therapy [151].

\section{Reconstruction of sternal bone defect after DSWI in cardiac surgery}

Wire re-cerclage was a commonly used method for addressing sternal approximation in patients with sternal dehiscence after DSWI [72,86,102]. The quality of residual sternal bone or its loss makes re-cerclage troublesome or even risky for achieving sternal stability. The occurrence of extensive adhesions below the sternum in DSWI patients increases the risk of damage to the right ventricle and bypass grafts when peri-, trans- and parasternal wiring techniques are used $[72,99,100]$. Today, stable osteosynthesis of the sternum, particularly using transverse plates, has become a method of treatment of post-DSWI sternal dehiscence [76]. Voss at el reported an institutional experience with Titanium Sternal Fixation system ${ }^{\mathrm{TM}}$ plates for sternal non-union in 15 patients, in which four patients had more than two previous attempts to stabilize the chest with some modification of wire re-cerclage, and four patients were treated for DSWI with NPWT prior to plating. All patients were successfully stabilized and healed, with one patient from the DSWI group experiencing a late infection recurrence and one dying from a complication not related to plating [152]. Larger experience with the same plate system has been reported by Baillot et al in a group of 92 patients after DSWI [46]. They achieved chest stabilization in all cases, with 9 patients $(9.8 \%)$ undergoing further procedure for late infection recurrence including removal of the plate with no impact on sternal stability [153]. Chest stability after a healed DSWI improves respiratory function, augments wound healing processes, shortens in-hospital stay, and improves patient quality $[46,72,80]$. Plating seems to be an effective method of chest wall stabilization, but may fail in cases of massive loss of chest bone tissue. In these cases, the bone residue does not allow sufficient anchoring for the plates or there is a large bone tissue gap. Shear forces may loosen screws and threaten stability. Persistent pain and respiratory discomfort were also reported in this case [154]. A conventional surgical approach to manage the large residual bone defect leaves the 
sternotomy wound unstable and employs the greater omentum or a muscle flap to fulfill any dead spaces $[93,95,99,103]$. This approach resulted in sternal instability and flap-related morbidity even when wounds were well-healed [154]. Some case reports have included the use of an autologous bone iliac crest graft or allogenous fibula graft to supply residual bone defects after DSWI $[155,156]$. Marulli reported the first use of an allogenous sternocostal bone graft for sternal reconstruction after chondrosarcoma removal [157]. Consequently, Dell'amore et al described four patients who were managed with the same technique with no wound healing complications and preserved chest wall stability [158]. The same authors proposed this technique for major post-DSWI defects, and [159] Kalab et al described the possibility of using an allogenous calva bone graft to address this issue. Allogenous bony grafts being fixed with transverse plates in mentioned cases [158-160]. Bone allograft usage for transplantation is under law restriction of local governments and European Association of Tissue Banks [161,162].

\section{Options in soft tissue defects reconstruction after DSWI in cardiac surgery}

There are a broad range of possibilities for managing sternal soft tissue defects caused by DSWI. In the case of minor defects, a direct suture with tissue undermining can be effective. In wide dehiscence, some type of flap transfer is needed and excessive bone and soft tissue loss are dependent on close co-operation between the cardiac and reconstructive surgeons. There are two crucial conditions influencing the reconstructive strategy. The first condition is the size of the defect, while the second is the vascular network, which would optimally remain uncompromised after primary surgery or previously failed reconstructions. Although various flaps and their modifications have been proposed, none have been found to be a reconstructive option for all defects $[97,163,164]$, therefore Greig et al suggested a simple classification system to address the choice of flap based on the size and location of the post-sternotomy defect (Table 6) [165]. It is not possible, however, to follow this classification system because various factors and conditions influencing the result must be taken into the account.

\begin{tabular}{lll}
\hline Wound type & Site of sternal wound & Recommended flap for reconstruction \\
\hline Type A & Upper half sternum & Pectoralis major \\
\hline Type B & Lower half sternum & Combined pectoralis major and rectus abdominis bipedicled flap \\
\hline Type C & Whole sternum & Combined pectoralis major and rectus abdominis bipedicled flap \\
\hline
\end{tabular}

Table 6. Classification of sternal wounds according to anatomical site (modified from Greig et al [165])

In 1976, Lee et al were the first to report on the use of a pedicled greater omentum to fulfill the large defect after total sternectomy [93]. In 1980, Jurkiewicz et al introduced the bilateral pectoralis turnover flap for the same indication. Although various muscle flaps, along with their modifications have been reported, there is still debate about using muscular versus 
cutaneous or fasciocutaneous flaps to cover difficult defects. It has been presumed that muscular flaps carry richer vascular networks, thus bringing a better blood supply to the defect, along with a higher antibiotic concentration. Recent studies, however, did not support this hypothesis and suggested that muscle flaps have no particular advantage over fasciocutaneous flaps in terms of improving vascularity and eradicating infection [166,167]. Nevertheless, there is still a reasonable argument for muscular flaps as additional muscle brings enough tissue for planed reconstruction.

\subsection{The pectoralis major flap}

The pectoralis major provides many qualities that make it a suitable flap choice for covering sternal defects including close proximity to the sternotomy, triple blood supply (the thoracoacromial artery, perforating branches of the internal thoracic artery and the lateral thoracic artery), and versatility of the flap as either the thoracoacromial or internal thoracic artery vascular axis may be used separately to nourish the flap [168]. Netcher et al did not show an adverse influence of the pectoral muscle transposition on pulmonary function [169], moreover, pain and loss of strength appeared to be related more to sternal instability rather than to the muscle transposition. Additionally, Cohen et al reported an improvement of spirometric parameters (forced vital capacity and standardized forced expiratory volume in 1 second) before and after pectoral flap transfer, thus supporting the crucial role of the flap in chest stabilization [170].

\subsubsection{Pectoral muscle advancement flap}

The pectoral muscle advancement flap is based on the thoracoacromial pedicle and is considered to be the best muscular reconstructive option in this area due to its technical simplicity, versatility, and low risk of flap loss $(<3 \%)$. There is, however, some risk of skin island necrosis or partial necrosis $(\approx 30 \%)$ [171, 172]. Dissection and elevation of the flap begins along the median line of the costal grid until reaching the relatively avascular plane under the muscle. Undermining then proceeds by blunt dissection laterally as necessary to achieve approximation of the bilateral flaps at the median line without tension. The thoracoacromial vascular pedicle is visible at the dorsal plane of the muscle. The humeral and clavicular insertion of the muscle can be released if needed. If the distal portion of the sternum is exposed, dissection continues distally under the anterior sheet of the rectus abdominis which then becomes part of the flap [164]. Though the flap is elevated mostly in a myocutaneous fashion $[73,163,164,173,174]$, Brutus et al reported on the use of a pectoral muscle flap released from skin for covering the entire sternal defect [175]. Completely dissected and freed from all of its origins, the pectoral muscle was advanced medially on the skeletonized vascular pedicle to cover the full length of the sternal defect. Separating the skin from the muscle can jeopardize the cutaneous blood supply and increase risk of skin necrosis. This technique included the release of humeral insertion from a short skin counter incision [175].

If the defect is wide, it may be difficult to achieve tension-free suturing in the midline. A modification of the advancement flap with a skin relaxing incision has been reported [176]. Majure et al proposed shifting the skin island over the pectoralis muscle in the $\mathrm{V}-\mathrm{Y}$ manner to 
cover the entire sternotomy defect, but this method requires secondary skin grafting from an island donor site [177]. This technique was adopted and modified by Molitor et al [178]. The skin island is dissected, while the underlying muscle fascia and pectoralis major are elevated and completely released from their insertions to the humerus, sternocostal junctions and abdominal muscles. The thoracoacromial vessels are visualized and the clavicularinsertion of the muscle is released to achieve comfortable advancement of the flap to the defect. The secondary defect in the lateral thoracic wall is then sutured in the V-Y manner and no skin graft is needed [178].

Finally, the pectoralis major musculocuteneous flap can be mobilized in a rotational manner when the skin-muscle flap is elevated based on the thoracoacromial pedicle and is rotated to the defect [179].

\subsubsection{Pectoral muscle turnover flap}

This flap is based on perforators of the internal mammary artery. Once the skin is elevated off of the anterior pectoralis fascia, the distal rib, proximal clavicular origin and humeral insertion of the muscle are divided. Then, the thoracoacromial pedicle is dissected and ligated, and the pectoralis major is elevated from lateral to medial until the perforating vessels from the internal thoracic artery are identified, and the muscle is then turned into the defect. To gain additional width of the narrowing humeral portion of the flap, fascial release incisions along the direction of the muscle fibers can be done. By this maneuver an average increase in flap width of $5.8 \mathrm{~cm}$ can be obtained [181]. Usually bilateral turnover muscle flaps are used [94,95]. The disadvantages of this flap include limitations in the distal parts of the sternum, need for wide skin undermining, dependence on an intact internal mammary artery, and an unfavorable aesthetic consequence including a missing anterior axillary line and parasternal subcutaneous tissue bulkiness [95].

\subsection{The rectus abdominis flap}

This flap was first used in cardiac surgery by Jurkiewicz in the case of a pectoral turnover flap failing to cover the entire defect $[94,95]$. To cover the sternal defect, the rectus abdominis flap is used exclusively as a pedicled flap based on the superior epigastric artery [182]. Because this artery is the terminal branch of the internal thoracic artery, the flap cannot be used if the ipsilateral internal thoracic artery was used for bypass grafting. The functional consequences of using the rectus abdominis to reconstruct sternal defects were assessed by Netscher et al [169]. They found no significant differences in abdominal wall function between the groups of patients in whom the rectus muscle was used for reconstruction and the group without sternal wound complications. There is a higher associated risk of hernia (11\%) or fascial weakness $(42 \%)$ as was reported $[103,183]$. The rectus abdominis flap may be used as a muscular flap $[94,184)$ or as a myocutaneous island flap [171,185].

\subsubsection{Rectus abdominis muscular flap}

The rectus abdominis muscular flap may be dissected without the use of a skin island. The skin incision continues distally to the desired point according to the necessary flap length. The 
skin is undermined over the rectus fascia to expose the muscle. Then, the rectus anterior sheet is divided and the muscle is dissected and mobilized. The distal pedicle inferior epigastric vessels are ligated and divided. The muscle is then turned to the defect. The exposed muscle and pedicle is covered either by skin suture or grafting [95].

\subsubsection{Rectus abdominis musculocutaneous flap}

The myocutaneous flap can have a skin island oriented vertically along the used muscle(VRAMvertical rectus abdominis muscle flap), or horizontally, as well as perpendicular to the muscle distal to the umbilicus (TRAM-transverse rectus abdominis muscle flap). The transverse orientation permits harvest of a larger skin paddle. Dissection of the VRAM starts with marking the skin island over the used muscle. The skin component should be placed medially near the umbilicus to include important periumbilical perforators. The skin island is cut and the skin overlying the muscle is undermined above the muscle fascia. Then, the rectus sheet is divided bilaterally at the edges of the muscle and the muscle is dissected and mobilized. The distal pedicle inferior epigastric vessels are ligated and divided. Theflap is then turned to the defect. The TRAM is marked transversely under the umbilicus and skin island which can involve the entire area between the umbilicus and symphysis bilaterally. The flap is dissected in the similar way as the VRAM flap, but the mobilization of the skin island continues away from the muscle pedicle crossing the midline to the contralateral side [171,185]. Care must be taken to avoid pedicle compression passed through the subcutaneous tunnel to the sternal defect.

\subsection{Combined pectoral muscle - Rectus abdominis muscle flap}

For full length sternal defects, a combined pectoralis major and rectus abdominis flap (Pec-Rec flap) was proposed [186]. The flap is predominantly created on the left side, but can occasionally be bilateral. The skin overlying the pectoral muscle is elevated up to the mid-axillary line laterally and from the clavicle to the inferior costal line in a vertical direction. The pectoral muscle iselevated whilepreserving thethoracoacromialvessels. Themuscleis detached fromitshumeral insertion and medially from one third of the clavicle. Dissection of the flap continues distally while elevating the thoracoepigastric fascial attachments from the chest wall between the pectoralis major and the rectus abdominis. Distal to the fascia, the anterior sheet of the rectus abdominis is incised medially and laterally and the muscle is mobilized from the posterior fascia. The muscular connections of the rectus abdominis to the distal ribs are detached as the last step of flap harvesting. The superior epigastric artery can be preserved or it can be divided close to the muscle if necessary for better medial transposition of the flap [186].

\subsection{The latissimus dorsi muscle flap}

The latissimus dorsi flap is based on a thoracodorsal artery that has not been jeopardized by previous cardiac surgery. Moreover, a large flap can be harvested (the main surface area of muscle is $105 \mathrm{~cm}^{2}$ for women and $192 \mathrm{~cm}^{2}$ for men) [187]. The main disadvantages of this flap include the need for a lateral decubital position during flap harvesting that can endanger patients with large sternal bone defect and sternal instability and shoulder functional limitation followed latissimus dorsi muscle harvesting. Patients who are dependent on their 
shoulder girdle strength, such as paralytic patients in a wheelchair or walker dependent patients, may endorse strength difficulties after muscle harvesting as well as tennis and golf players or those whose profession involves overhead tasks [187]. Up to $50 \%$ of patients may complain of localized numbness at the harvesting area [172].

Usually the muscle from the non-dominant side is used. The arc of rotation and position of the skin island is assessed and marked. The skin component is predominantly oriented perpendicular to the muscle fibers near the vertebral column, but a longitudinal course from the medial axillary line to the medial caudal dorsum is also possible. The flap is dissected using the whole muscle up to the pedicle. Thoracodorsal vessels are skeletonized and humeral muscle insertion is divided, allowing an additional $4-10 \mathrm{~cm}$ of flap advancement. Then the flap is transposed to the defect through a subcutaneous tunnel superficial to the pectoralis major [188,189].

\subsection{Breast flap}

Obese female patients with large breasts are at higher risk of sternal dehiscence due to the infero-lateral tension of the breasts, especially on the distal third of the sternotomy [72].This instability results from the greater protrusion of the lower thorax and abdomen during respiration, greater dimensions of the lower versus the upper thorax, the concentration of forces from the attachment of the ribs, and the reduced thickness of the lower sternum [72]. Therefore a special bandage, supporting bra, or other garment is used to release the tension resulting from large breasts. The technique of covering the sternal dehiscence with a bilateral pectoral muscle advancement flap with simultaneous breast reduction has been reported [190-192]. Large breasts carry an enormous amount of relatively well vascularized tissue that can potentially be used to cover the sternal defect $[193,194]$. The vascular supply of the breast is basically the same as the pectoral muscle. There is, however, a unique vascular network inside the breast gland, known as Würinger's septum. Uygur et al reported a method of covering a large distal sternum defect with bilateral fasciocutaneous V-Y flaps from the breasts [193]. These flaps were anatomically based on the Würinger's septum [193,195]. Another method has been suggested by Hamdi et al [196]. They performed a septum-based therapeutic mammoplasty on two patients. The principle of this technique is to reduce breast mass with harvesting of a large fasciocutaneous flap from the inferomedial part of the breast

Another possibility for utilizing the breasts to cover the sternal defect is a Cyclops' flap. In this technique the whole breast is transposed to the central or even contralateral chest defect, so that the areola is centralized. The breast flap in this case is based on the lateral and central vascular pedicles of the breast $[197,198]$.

\subsection{Omentum}

The greater omentum is a well-vascularized tissue with plentiful lymphatic drainage and angiogenic activity $[93,98,199]$. Its size can be up to $36 \times 46 \mathrm{~cm}$ and is reliable to cover large defects. It is difficult, however, to predict the flap size preoperatively because the greater omentum volume has no direct correlation with the patient's habitus [200]. The omentum can be transposed to the defect in various ways such as, pedicled on both gastroepiploic arteries 
for defects in the distal part of sternotomy wound or mobilized on either of the gastroepiploic vessels to cover full-length sternotomy defects [201-203]. Passing the omental flap subcutaneously from the upper portion of the laparotomy bears up to a $21 \%$ risk of late herniation [202], thus, a better solution seems to create the transdiaphragmatical tunnel just right of the falciform ligament [204]. The risk of abdominal cavity infection is rare [205], but the traction on the gastroepiploic artery can cause motility disturbances of the stomach and duodenum [206], and one case of fatal cecum volvulus have been reported [207]. Laparoscopic harvesting seems to be promising in reduction of access complications and pain [108,208,209].

\subsection{Microsurgical flaps}

Microsurgical free flaps can be used to cover sternal defects in particular situations. This technique, due to its duration and technical complexity, should serve as a last treatment option. The use of the tensor fascia lata myocutaneous flap, rectus abdominis myocutaneous flap and deep inferior epigastric artery fasciocutaneous flap for this indication have been reported [210]. As a donor vessel, the thoracoacromial, internal thoracic or cervical vessels can be used. The cephalic vein attached to the thoracoacromial or cervical arteries, can be used for lengthening the donor vessel (arterio-venous loop) [210,211].

\subsection{Specifics of care after flap surgery in cardiac surgery}

There are special requirements for care after flap surgery. In general, it is important to protect the blood circulation within the flap, maintaining both general and local hemodynamics. Vascular spasm must be prevented by using vasodilator drugs if possible. The elevated and transposed flap usually loses most of its physiological blood and lymphatic network and is dependent only on a small part of it, so varying degrees of edema are usually present. Large swelling of the tissue compresses the capillaries and decreases the blood flow in the flap, increasing the tension on the suture. Corticosteroids are used to prevent swelling for several days in most flap surgeries unless serious contraindications are present. The flap must be kept from topical pressure, particularly in places of passing vascular pedicle and in peripheral parts of the flap because of limited vascular competence. Undoubtedly, changes in body position influence the blood supply of the flap. Furthermore, stretching of the arms causes increased tension on the medial sternal suture. In the case of the pectoral and latissimus dorsi flap, the use of muscles of the shoulder girdle should be avoided. When using the rectus abdominis flap, the abdominal wall must be relaxed and supported with bandages for several weeks to prevent hernia formation. Finally, nutritional support with enteral feeding is essential for successful healing.

\section{University hospital Olomouc management of DSWI after cardiac surgery}

\subsection{Adopted treatment strategy for DSWI}

We retrospectively analyzed our experience with treatment strategies of DSWI since February 2002, when our department was established. A total of 100 patients fulfilling CDC criteria [5] 
for DSWI were enrolled until September 2011 with an overall incidence of DSWI of $1.36 \%$. The results of 28 patients (March 2002-June 2004) primarily treated with closed chest irrigation using diluted iodine solution were compared with 76 patients (September 2004 to September 2009) treated with NPWT (VAC ATSTM, KCI, St. Antonio, USA). A standardized protocol for first-line application of NPWT is depicted in Figure 1. Six patients from the interim period (June to September 2004) when closed irrigation and NPWT were combined were excluded from the analysis. Both groups had comparable demographic and perioperative characteristics, however, the NPWT arm had an insignificant trend towards advanced age, higher logistic EUROSCORE, more complex primary cardiac surgery. No difference in the rate of causative agent was found, with SA and CONS identified in almost 70\% of cases. Escherichia coli (5.8\%) and Pseudomonas species (7.2\%) as leading Gram negative strains were cultivated. The time to presentation of DSWI was insignificant between groups ( $17.5 \pm 15.0$ vs. $13.8 \pm 16.3, \mathrm{p}=0.55)$ as well as readmission for late clinical presentation of DSWI (38.6\% vs. 50\%, p=0.12). Although the overall length of DSWI therapy was comparable $(14.3 \pm 11.9$ vs. $14.9 \pm 7.9$ days, $\mathrm{p}=0.82)$, NPWT required more dressing changes $(5.4 \pm 2.3$ vs. $1.8 \pm 1.2, \mathrm{p}<0.001)$, but was associated with substantially lower failure of primary therapy (5.1 vs. $39.2 \%, \mathrm{p}<0.01$ ) with closed chest irrigation. In-ICU stay was significantly shorter in the NPWT group $(209.6 \pm 331.3$ vs. $516.1 \pm 449.5$ hours, $\mathrm{p}<0.001)$, nevertheless, shortened in-hospital stay $(40.2 \pm 16.3$ vs. $48.8 \pm 29.2$ days, $\mathrm{p}=0.16)$ was insignificant in this group. Addressing mortality, 30-day and 1-year mortality was considerably lower in the NPWT arm (3.9 vs. $21.4 \%, \mathrm{p}<0.05,15.8$ vs. $39.2 \%$, $\mathrm{p}<0.05$, respectively). A Kaplan-Meier 1 year-survival analysis is shown in Figure 2 . The risk of major bleeding complications was comparable between groups, with 2 patients $(3.6 \%)$ from the closed chest irrigation group having erosion of venous bypass graft and right ventricle (RV), and 3 patients (3.9\%) from the NPWT group, including 1 debridement-related and 2 spontaneous injuries of the RV. Employment of local and advancement flaps for covering of residual defects was higher in the NPWT groups (65.7 vs. $17.8 \%, \mathrm{p}<0.01$ ). Our experience showed that NPWT is effective in the treatment of DSWI, compared with closed chest irrigation, leading to lower failure of primary therapy, ICU stay, and better short- and midsurvival of patients. We did not prove NPWT influenced length of in-hospital stay or risk of major bleeding, however, residual defects required more complex approach to assure sternal stability and covering defects $[119,130]$.

\subsection{Sternal stabilization and management of residual bone defects}

Non-complicated sternal dehiscence following DSWI that is not associated with considerable bone loss can be stabilized with transverse titanium plates (Titanium Sternal Fixation system ${ }^{\mathrm{TM}}$, Synthes, Switzerland) at our department. Plates are applied on the anterior surface of the ribcage to achieve sufficient stability of the chest wall while minimizing the risk of an iatrogenic injury to the heart. From January 2008 to September 2012 we performed 31 sternal wall reconstructions using the Titanium Sternal Fixation system ${ }^{\mathrm{TM}}$. In four cases, osteosynthesis was applied to treat a sterile mechanical dehiscence of the median sternotomy, while 27 other chest osteosyntheses were performed after DSWI when wound bed decontamination was achieved with NPWT. In the postoperative period, 2 patients $(7.4 \%)$ needed to be operatively revised due to bleeding from pectoral flap advancement; in 3 cases $(11.1 \%)$ the plates needed 


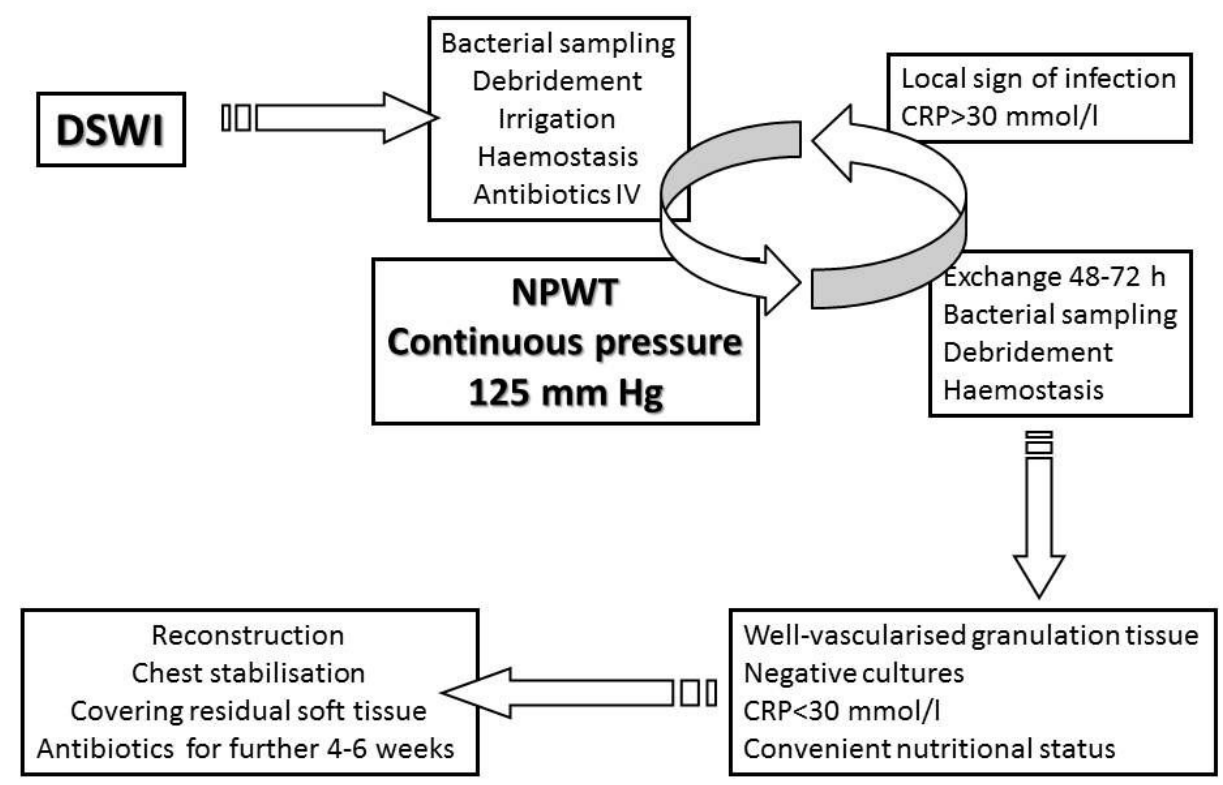

Figure 1. The first-line application protocol of NPWT for treatment of DSWI

to be removed for soft tissue healing complications post-reconstruction. Nevertheless, removal could be postponed until satisfactory healing of the sternal bones was achieved. One patient (3.7\%) had to be drained for iatrogenic pneumothorax. We also retrospectively analyzed 21 patients with post-DSWI sternal dehiscence from January 2005 to January 2010, comparing 11 patients with re-cerclage wiring and 10 patients with titanium plate osteosynthesis. DSWI was managed with the same protocol of NPWT prior to reconstruction mentioned above [119]. Plating was accompanied by a lower risk of therapy failure (1\% vs. 1.85\%), shorter in-hospital stay (22 vs. $59 \%)$, and reduction in costs ((€8,243 vs. $€ 33,365)$ (unpublished data).

In cases of minor sternal bone loss, we use an autologous bone graft harvested from the patient 's own iliac crest. The graft is preferably prepared as bi-cortical. There is a limit to the extent of bone tissue that can be solved through this method. Fixation of the bone graft and chest stabilization is done in the manner described above. From 2009 to 2012 we used this method in 2 patients. In both cases the wounds healed successfully and the sternal wall regained full stability. Both sternal defects represented partial loss of bone tissue from 6 to $8 \mathrm{~cm}$ in length.

Based on this experience, we decided to apply a novel approach for the treatment of massive bone loss after DSWI, by supplying the bone defect with an allogenous bone graft. It allows 


\section{Survival Functions}

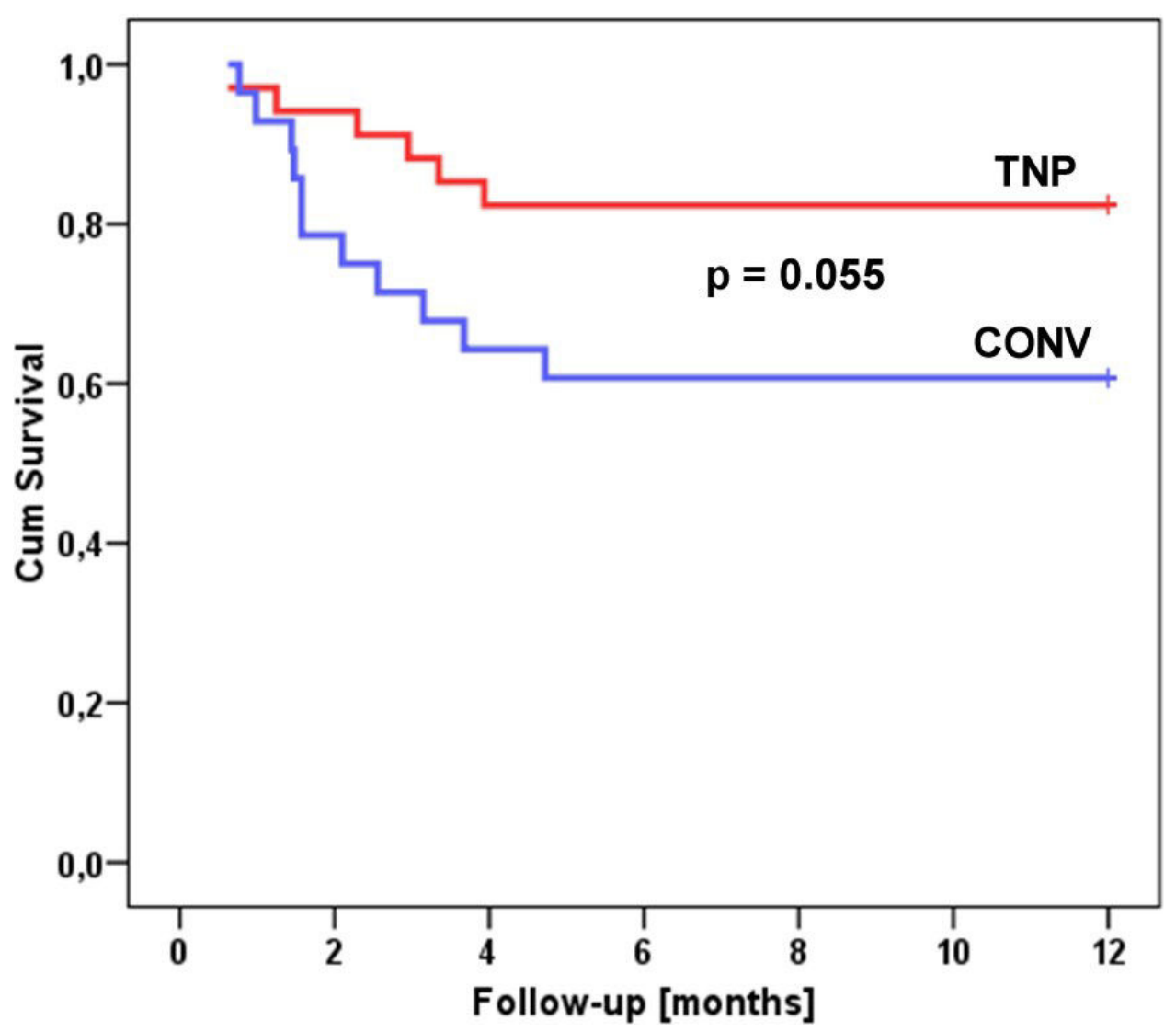

Figure 2. 1-year Kaplan-Meier survival analysis comparing NPWT with conventional therapy (CONV)

treating large sternal defects in the same way as a total or near-total sternectomy and fixed properly with titanium plate system ensures chest cage stability. An allogenous bone transplant doesn't contain any vital bone marrow cells, which eliminates difficulties in immunogenetic acceptance of the graft by a patient; it represents a biological tissue transfer, which even under conditions of maximum precautions represents a minor risk for transmission of viral or bacterial infections. An allogenous graft must meet legislative criteria from the Czech Republic and the European Association of Tissue Banks [161,162]. Prior to graft harvesting, each donor is cross-checked for registration within the National Registry for organ donation refusal. All deceased donors treated for infectious disease, sepsis, malignant tumors, or systemic and autoimmune diseases at the time of death are withdrawn from the donor list. Donor blood serum samples are tested for antibodies and HIV types 1 and 2, hepatitis B surface 
antigen (HbsAg), hepatitis C antibodies (anti-HCV), and HTLV I and II antibodies. Harvest of a sternal bone graft is performed under strictly sterile conditions by a team from the National Tissue Center in Brno. The graft is harvested under sterile conditions and stored in the freezer at $-80^{\circ} \mathrm{C}$. Prior to its clinical use, the graft is thawed at $4-6^{\circ} \mathrm{C}$ for 12 hours, soaked with a $1 \%$ gentamicin solution, prepared for its final shape, and stored in the freezer again at $-80^{\circ} \mathrm{C}$. If bacterial sampling is negative, the graft is thawed for 12 hours before transplantation, and submerged in a bath with $1 \%$ neomycin solution immediately before surgery.

Inherent surgical technique is modified by a more aggressive debridement of residual chest bone or ribs (1-2 cm safety line). Afterwards, the bone graft is adjusted to the size of the bone defect and fixed with plates anchored by self-cutting or self-drilling cortical screws. An uneven surface and tiny bone deficiency can be filled in with a spongy bone which is prepared from another graft provided by the tissue bank (femoral or tibial graft source). Residual soft tissue defect is covered with monolateral or bilateral pectoral muscle flap transfer. Within the postoperative period, it is strongly recommended to avoid excessive coughing or any rough mechanical strain on the sternal wall. Intravenous antibiotics are administered for at least three weeks after the reconstruction. Between January 2010 and September 2012, we performed six reconstructions of the sternal wall using an allogenous bone graft. We used a cadaveric sternum in four cases (Figure 3), and due to a lack of allografts, we had to use a calva bone in one patient (Figure 4) and a split femoral diaphysis in one patient. Successful healing after the reconstruction was achieved in five cases (83\%), while one patient required additional treatment for partial skin necrosis. One obese female experienced flap failure and died from multiple organ failure. Follow-up of the other patients at 3, 6 and 12 months after reconstruction proved stability of the chest wall. A radio-isotope scan using technetium as a tracer of autologous leukocytes (Technetium-HMPAO) carried out at 3, 6 and 12 months after the reconstruction showed a high level of healing activity within the area of the allogenous bone implant, and further chest wall stability with allograft union was confirmed through 3D-CT evaluation done 5 to 7 months after the reconstruction (unpublished data).

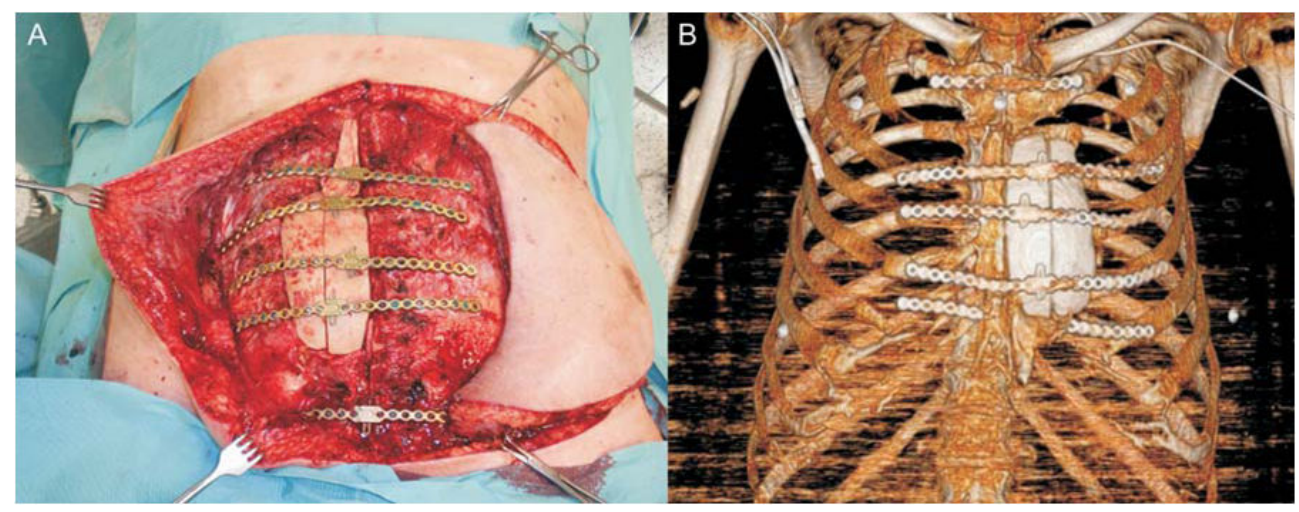

Figure 3. Cadaveric sternal allograft and its use for large residual bone defect 

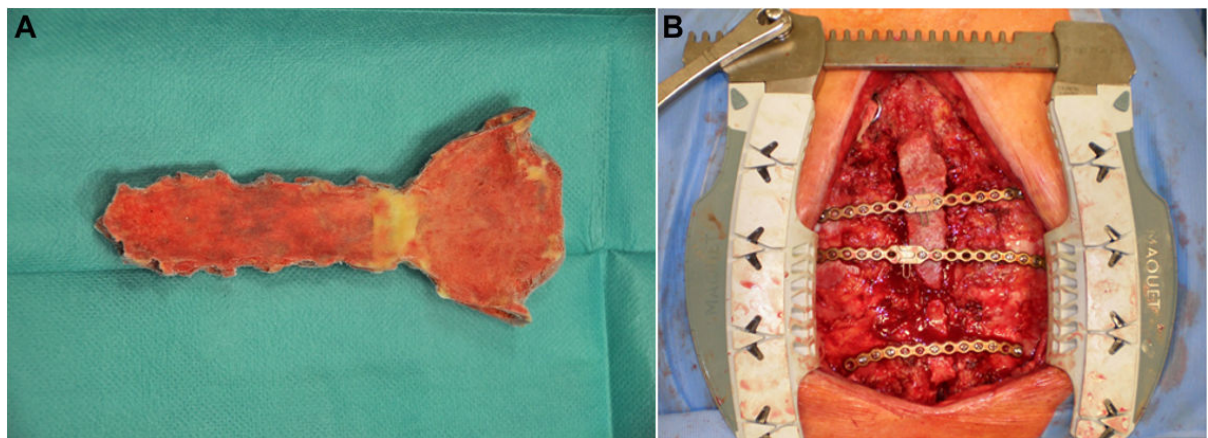

Figure 4. Cadaveric calva bone allograft in large bone defect repair and CT reconstruction showing the bone re-union

\subsection{Reconstruction of residual soft tissue defects}

In a group of 76 consecutive patients primarily treated with NPWT for DSWI from September 2004 to September 2011, 19 residual defects (25\%) were closed by direct suture, and 57 patients $(75 \%)$ underwent flap transfer to achieve reliable tension-free suture. All but 2 patients $(2.7 \%)$ underwent sternal stabilization with re-cerclage $(61.8 \%)$ or transverse plates with or without bone graft (35.5\%). Local fasciocutaneous advancement was used in 12 patients $(21.1 \%)$, bilateral pectoralis advancement flap in 35 patients (61.2\%), monolateral pectoralis flap with $\mathrm{V}-\mathrm{Y}$ skin island in 7 patients $(12.3 \%)$, bipedicled pectoral and rectus abdominis flap in 1 patient $(1.7 \%)$, and vertical rectus abdominis flap in 2 patients (3.5\%). We faced 2 flap failures (3.5\%) and one whole monolateral pectoralis flap with V-Y skin island was lost due to vascular pedicle thrombosis, with $50 \%$ of the mass of the VRAM flap needing to be removed for flap necrosis. Minor healing complications requiring further local wound care were noted in 15 cases $(26.3 \%)$. While the bilateral pectoralis advancement flap is a technique used by cardiac surgeons, other flaps used for covering larger residual soft tissue defects are utilized by plastic surgeon. The pectoral major flap with V-Y skin island is the first choice (Figure 5). When the defect is wide and deep, or in a female patient with large breasts, the VRAM pedicled flap is considered. If these two options fail or are not accessible, the latissimus dorsi pedicled flap is the next choice, and as a last resort, the microsurgical transfer is taken into account.

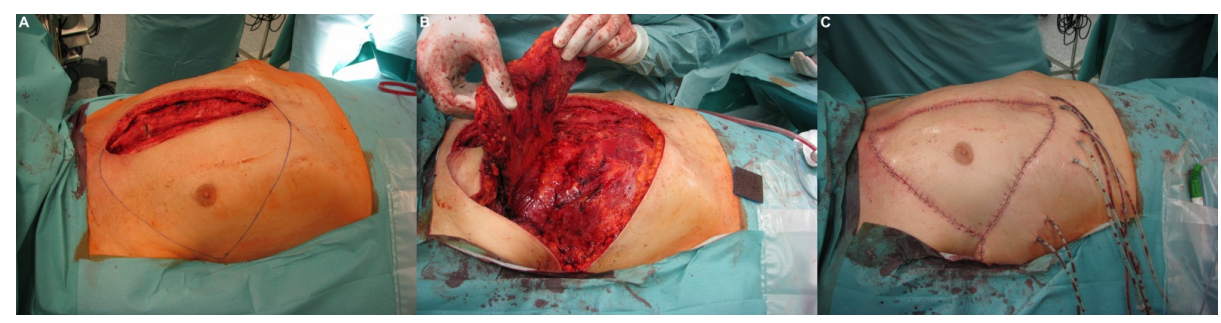

Figure 5. Technique of unilateral pectoral muscle flap advancement with $\mathrm{V}$-Y skin island 


\section{Conclusion}

DSWI remains a potentially fatal complication of cardiac surgery. Even though risk factors for development of DSWI have been identified, few are modifiable. Tight perioperative glycemic control, proper surgical technique, skeletonization of IMA grafts particularly in diabetics, and primary stable sternal approximation for high risk patients including diabetics, obese, immunosuppressed or those with COPD seem to reduce the risk of DSWI. Thanks to the unique combination of closed and open chest treatment, NPWT positively influences the survival of DSWI patients even at long-term follow-up in comparison with conventional therapy. Transverse titanium plates alone or with auto- or allograft bone allows chest cage stability irrespective to the bone mass loss. Better quality of life and lower extent of soft tissue defect might be promising for these patients who faced sternal instability and considerable flaprelated morbidity some/few years ago. Plastic surgeons should be included in team planning post-DSWI sternotomy wound closure, not only called when previous closure attempt failed or residual defect seems to be extent.

\section{Author details}

Martin Šimek ${ }^{1 *}$, Martin Molitor ${ }^{1}$, Martin Kaláb², Patrick Tobbia ${ }^{3}$ and Vladimír Lonský ${ }^{1}$

*Address all correspondence to: martin.simek@c-mail.cz

1 Department of Cardiac Surgery, University Hospital Olomouc, Olomouc, Czech Republic

2 Department of Plastic Surgery, University Hospital Bulovka, Prague, Czech Republic

3 Department of Medicine, Cone Health, University of North Carolina, Greensboro, NC, USA

\section{References}

[1] Dalton, M. L, Connally, S. R, \& Sealy, W. C. Julian's reintroduction of Milton's operation. Ann Thorac Surg (1992). , 53, 532-533.

[2] Milton, H. Mediastinal surgery. Lancet (1897). , 1, 872-5.

[3] Julian, O. C, Lopez-belio, M, Dye, W. S, Javid, H, \& Grove, W. J. The median sternal incision in intracardiac surgery with extracorporeal circulation: a general evaluation of its use in heart surgery. Surgery (1957). , 42, 753-61.

[4] Balaguer, J. M, Umakanthan, R, Leacche, M, \& Byrne, J. G. Minimally invasive cardiac surgery. Curr Probl Surg. (2012). , 49, 529-49. 
[5] Mangram, A. J, Horan, T. C, Pearson, M. L, Silver, L. C, \& Jarvis, W. R. The hospital infection control practise advisory committee. Guidelines for prevention of surgical site infection. Infect Control Hosp Epidemiol (2002). , 20, 247-78.

[6] Loop, F. D, Lytle, B. W, Cosgrove, D. M, et al. Maxwell Chamberlain memorial paper. Sternal wound complications after isolated coronary artery bypass grafting: early and late mortality, morbidity, and cost of care. Ann Thorac Surg (1990). , 49, 179-87.

[7] Milano, C. A, Kesler, K, Archibald, N, Sexton, D. J, \& Jones, R. H. Mediastinitis after coronary artery bypass graft surgery. Risk factors and long-term survival. Circulation (1995). , 92, 2245-51.

[8] Braxton, J. H. Marrin CAS, McGrath PD, et al. Mediastinitis and long-term survival after coronary artery bypass graft surgery. Ann Thorac Surg (2000). , 70, 2004-7.

[9] Eklund, A. M, Lyytikainen, O, Klemets, P, et al. Mediastinitis after more than 10,000 cardiac surgical procedures. Ann Thorac Surg (2006). , 82, 1784-9.

[10] The Parisian Mediastinitis Study GroupRisk factors for deep sternal wound infection after sternotomy: a prospective, multicenter study. The Journal of Thoracic and Cardiovascular Surgery (1996). , 111, 1200-1207.

[11] Hollenbeak, C. S, Murphy, D. M, Koenig, S, Woodward, R. S, Dunagan, W. C, \& Fraser, V. J. The clinical and economic impact of deep chest surgical site infections following coronary artery bypass graft surgery. Chest (2000). , 118, 397-402.

[12] Filsoufi, F, Castillo, J. G, Rahmanian, P. B, et al. Epidemiology of deep sternal wound infection in cardiac surgery. J Cardiothorac Vasc Anesth (2009). , 23, 488-94.

[13] Tang GHL, Maganti M, Weisel RD, Borger MA. Prevention and management of deep sternal wound infection. Semin Thorac Cardiovasc Surg (2004). , 16, 62-9.

[14] Toumpoulis, I. K, \& Anagnostopoulos, C. E. Derose JJ Jr, Swistel DG. The impact of deep sternal wound infection on long-term survival after coronary artery bypass grafting. Chest (2005). , 127, 464-71.

[15] Risnes, I, Abdelnoor, M, Almdahl, S. M, \& Svennevig, J. L. Mediastinitis after coronary artery bypass grafting risk factors and long-term survival. Ann Thorac Surg (2010). , 89, 1502-10.

[16] Crabtree, T. D, Codd, J. E, Fraser, V. J, Bailey, M. S, \& Olsen, M. A. Damiano RJ Jr. Multivariate analysis of risk factors for deep and superficial sternal infection after coronary artery bypass grafting at a tertiary care medical center. Semin Thorac Cardiovasc Surg. (2004). , 2004, 16-53.

[17] Fowler VG JrO'Brien SM, Muhlbaier LH, Corey GR, Ferguson TB, Peterson ED. Clinical predictors of major infections after cardiac surgery. Circulation. 200;112(9 Suppl):I, 358-65. 
[18] Sjögren, J, Malmsjö, M, Gustafsson, R, \& Ingemansson, R. Poststernotomy mediastinitis: a review of conventional surgical treatments, vacuum-assisted closure therapy and presentation of the Lund University Hospital mediastinitis algorithm.Eur J Cardiothorac Surg (2006). , 30, 898-905.

[19] Matros, E, Aranki, S. F, Bayer, L. R, et al. Reduction in incidence of deep sternal wound infections: random or real? J Thorac Cardiovasc Surg (2010). , 139, 680-5.

[20] De Feo, M, Vicchio, M, Santè, P, Cerasuolo, F, \& Nappi, G. Evolution in the treatment of mediastinitis: single-center experience. Asian Cardiovasc Thorac Ann. (2011). , 19, 39-43.

[21] Upton, A, Roberts, S. A, Milsom, P, \& Morris, A. J. Staphylococcal post- sternotomy mediastinitis: five year audit. ANZ J Surg. (2005). , 75, 198-203.

[22] Sachithanandan, A, Nanjaiah, P, Nightingale, P, et al. Deep sternal wound infection requiring revision surgery: impact on mid-term survival following cardiac surgery. Eur J Cardiothorac Surg (2008). , 33, 673-8.

[23] Pritisanac, A, Gulbins, H, Rosendahl, U, \& Ennker, J. Outcome of heart surgery procedures in octogenarians: is age really not an issue? Expert Rev Cardiovasc Ther (2007).

[24] Prabhakar, G, Haan, C. K, Peterson, E. D, Coombs, L. P, Cruzzavala, J. L, \& Murray, C. F. The risks of moderate and extreme obesity for coronary artery bypass grafting outcomes: A study from the Society of Thoracic Surgeons' database. Ann Thorac Surg (2002). , 74, 1125-31.

[25] Furnary, A. P, Zerr, K. J, Grunkemeier, G. L, \& Starr, A. Continuous intravenous insulin infusion reduces the incidence of deep sternal wound infection in diabetic patients after cardiac surgical procedures. Ann Thorac Surg (1999). , 67, 352-60.

[26] Halkos, M. E, Puskas, J. D, Lattouf, O. M, et al. Elevated preoperative hemoglobin A1c level is predictive of adverse events after coronary artery bypass surgery. J Thorac Cardiovasc Surg (2008). , 136, 631-40.

[27] Toumpoulis, I. K, Theakos, N, \& Dunning, J. Does bilateral internal thoracic artery harvest increase the risk of mediastinitis? Interact Cardiovasc Thorac Surg (2007). , 6, 787-91.

[28] De Paulis, R, De Notaris, S, Scaffa, R, et al. The effect of bilateral internal thoracic artery harvesting on superficial and deep sternal infection: the role of skeletonization. J Thorac Cardiovasc Surg (2005). , 129, 536-43.

[29] Curtis, J. J, Clark, N. C, Mckenney, C. A, et al. Tracheostomy: a risk factor for mediastinitis after cardiac operation. Annals of Thoracic Surgery (2001). , 72, 731-734. 
[30] Rahmanian, P. B, Adams, D. H, Castillo, J. G, et al. Tracheostomy is not a risk factor for deep sternal wound infection after cardiac surgery. Annals of Thoracic Surgery (2007). , 84, 1984-1991.

[31] Hubner, N, Rees, W, Seufert, K, et al. Percutaneous dilatational tracheostomy done early after cardiac surgery-outcome and incidence of mediastinitis. The Thoracic and Cardiovascular Surgeon (1998). , 46, 89-92.

[32] Diehl, J. L, El Atrous, S, Touchard, D, et al. Changes in the work of breathing induced by tracheotomy in ventilator-dependent patients. American Journal of Respiratory and Critical Care Medicine (1999). , 159, 383-388.

[33] Banbury, M. K, Brizzio, M. E, Rajeswaran, J, et al. Transfusion increases the risk of postoperative infection after cardiovascular surgery. Journal of the American College of Surgeons (2006). , 202, 131-138.

[34] Gardlund, B, Bitkover, C, \& Vaage, J. Postoperative mediastinitis in cardiac surgery microbiology and pathogenesis. Eur J Cardiothorac Surg (2002). , 21, 825-30.

[35] Mekontso-dessap, A, Kirsch, M, Brun-buisson, C, \& Loisance, D. Poststernotomy mediastinitis due to Staphylococcus aureus: comparison of methicillin-resistent and methicillin-susceptible cases. Clin Infect Dis (2001). , 32, 877-83.

[36] San Juan R, Chaves F, López Gude MJ, Díaz-Pedroche C, Otero J, Cortina Romero JM, Rufilanchas JJ, Aguado JM.Staphylococcus aureus poststernotomy mediastinitis: description of two distinct acquisition pathways with different potential preventive approaches. J Thorac Cardiovasc Surg. (2007). , 134, 670-6.

[37] Jakob, H. G, Borneff-lipp, M, Bach, A, et al. The endogenous pathway is a major route for deep sternal wound infection. European Journal of Cardio-Thoracic Surgery (2000). , 17, 154-160.

[38] Kluytmans, J. A, Mouton, J. W, Ijzerman, E. P, et al. Nasal carriage of Staphylococcus aureus as a major risk factor for wound infections after cardiac surgery. The Journal of Infectious Diseases (1995). , 171, 216-219.

[39] Von Eiff, C, Becker, K, Machka, K, Stammer, H, \& Peters, G. Nasal carriage as a source of Staphylococcus aureus bacteremia. Study Group. N Engl J Med (2001). , $344,11-16$.

[40] San Juan R, Aguado JM, López MJ, et al. Accuracy of blood culture for early diagnosis of mediastinitis in febrile patients after cardiac surgery. Eur J Clin Microbiol Infect Dis. (2005). , 2005, 24-182.

[41] Tegnell, A, Aren, C, \& Ohman, L. Coagulase-negative staphylococi and sternal infections after cardiac operation. Ann Thorac Surg (2000). , 69, 1104-9. 
[42] Mekontso Dessap A, Vivier E, Girou E, Brun-Buisson C, Kirsch M.Effect of time to onset on clinical features and prognosis of post-sternotomy mediastinitis. Clin Microbiol Infect (2011). , 17, 292-9.

[43] Jonkers, D, Elenbaas, T, Terporten, P, et al. Prevalence of 90 days postoperative wound infections after cardiac surgery. European Journal of Cardio-Thoracic Surgery (2003). , 23, 97-102.

[44] Mekontso-dessap, A, Kirsch, M, Brun-buisson, C, \& Loisance, D. Poststernotomy mediastinitis due to Staphylococcus aureus: comparison of methicillin-resistant and methicillin-susceptible cases. Clin Infect Dis. (2001). , 32, 877-83.

[45] Mauermann, W. J, \& Sampathkumar, P. Sternal wound infection. Best Practice \& Research Clinical Anaesthesiology (2008). , 22, 423-436.

[46] Baillot, R, Cloutier, D, Montalin, L, et al. Impact of deep sternal wound infection management with vacuum-assisted closure therapy followed by sternal osteosynthesis: a 15-year review of 23,499 sternotomies. Eur J Cardiothorac Surg (2010). , 37, 880-7.

[47] Speir, A. M, Kasirajan, V, Barnett, S. D, \& Fonner, E. Jr. Additive costs of postoperative complications for isolated coronary artery bypass grafting patients in Virginia. Ann Thorac Surg (2009). , 88, 40-6.

[48] De Feo, M, Renzulli, A, Ismeno, G, \& Gregorio, R. Della Corte A, Utili R, et al. Variables predicting adverse outcome in patients with deep sternal wound infection. Ann Thorac Surg (2001). , 71, 324-331.

[49] Graf, K, Ott, E, Vonberg, R. P, Kuehn, C, Haverich, A, \& Chaberny, I. F. Economic aspects of deep sternal wound infections. Eur J Cardiothorac Surg (2010). , 37, 893-6.

[50] Ennker, I. C, Kojcici, B, Ennker, J, Vogt, P, \& Melichercik, J. Examination of the opportunity costs and turnover situation in patients with deep sternal infections. Zentralbl Chir (2012). , 137, 257-61.

[51] Moidl, R, Fleck, T, Giovanoli, P, Grabenwöger, M, \& Wolner, E. Cost effectiveness of V.A.C. therapy after post-sternotomy mediastinitis. Zentralbl Chir (2006). S, 189-90.

[52] Mokhtari, A, Sjögren, J, Nilsson, J, Gustafsson, R, Malmsjö, M, \& Ingemansson, R. The cost of vacuum-assisted closure therapy in treatment of deep sternal wound infection. Scand Cardiovasc J (2008). , 42, 85-89.

[53] Atkins, Z. B, \& Wolfe, G. Sternal Wound Complications Following Cardiac Surgery. In: Cuneyt N. (ed). Special topics in cardiac surgery. Rijeka, InTech; , 284-308.

[54] Lazar, H. L, Chipkin, S. R, Fitzgerald, C. A, Bao, Y, Cabral, H, \& Apstein, C. S. Tight glycemiccontrol in diabetic coronary artery bypass graft patients improves perioperativeoutcomes and decreases recurrent ischemic events. Circulation (2004). , 109, 1497-502. 
[55] Gandhi, G. Y, Nuttall, G. A, Abel, M. D, Mullany, C. J, Schaff, H. V, Brien, O, Johnson, P. C, Williams, M. G, Cutshall, A. R, Mundy, S. M, Rizza, L. M, \& Mcmahon, R. A. MM. Intensive intraoperative insulin therapy versus conventional glucose management during cardiac surgery: a randomized trial. Ann Intern Med. 200;, 146, 233-43.

[56] Bratzler, D. W, Houck, P. M, Richards, C, Steele, L, et al. Use of antimicrobial prophylaxis for major surgery: baseline results from the National Surgical Infection Prevention Project. Arch Surg. (2005). , 140, 174-82.

[57] Finkelstein, R, Rabino, G, Mashiah, T, et al. Vancomycin versus cefazolin prophylaxis for cardiac surgery in the setting of a high prevalence of methicillin-resistant staphylococcal infections. The Journal of Thoracicand Cardiovascular Surgery (2002). , 123, 326-332.

[58] Bolon, M. K, Morlote, M, Weber, S. G, et al. Glycopeptides are no more effective than beta-lactam agents for prevention of surgical site infection after cardiac surgery: a meta-analysis. Clinical Infectious Diseases (2004). , 38, 1357-1363.

[59] Friberg, O, Svedjeholm, R, Soderquist, B, Granfeldt, H, Vikerfors, T, \& Kallman, J. Local gentamicin reduces sternal wound infections after cardiac surgery: a randomized controlled trial. Ann Thorac Surg (2005). , 79, 153-61.

[60] Friberg, O, Dahlin, L. G, Källman, J, Kihlström, E, Söderquist, B, \& Svedjeholm, R. Collagen-gentamicin implant for prevention of sternal wound infection; long-term follow-up of effectiveness.Interact Cardiovasc Thorac Surg. (2009). , 9, 454-8.

[61] Bennett-guerrero, E. Ferguson TB Jr, Lin M, Garg J, Mark DB, Scavo VA Jr et al. SWIPE-1 Trial Group. Effect of an implantable gentamicin-collagen sponge on sternal wound infections following cardiac surgery: a randomized trial. J Am Med Assoc (2010). , 304, 755-62.

[62] Mavros, M. N, Mitsikostas, P. K, Alexiou, V. G, Peppas, G, \& Falagas, M. E. Gentamicin collagen sponges for the prevention of sternal wound infection: A meta-analysis of randomized controlled trials. J Thorac Cardiovasc Surg. (2012). , 144, 1235-40.

[63] Kaiser, A. B, Kernodle, D. S, Barg, N. L, et al. Influence of preoperative showers on staphylococcal skin colonization: a comparative trial of antiseptic skin cleansers. Annals of Thoracic Surgery (1988). , 45, 35-38.

[64] Byrne DNA, Cuschieri A. The value of whole body disinfection in the prevention of post-operative wound infection in clean and potentially contaminated surgery. Surgical Research Communications (1992). , 12, 43-52.

[65] Perl, T. M, \& Golub, J. E. New approaches to reduce Staphylococcus aureus nosocomial infection rates:treating S. aureus nasal carriage. Annals of Pharmacotherapy (1998). S, 7-16. 
[66] Cimochowski, G. E, Harostock, M. D, Brown, R, et al. Intranasal mupirocin reduces sternal wound infection after open heart surgery in diabetics and nondiabetics. Annals of Thoracic Surgery (2001). , 71, 1572-1578.

[67] Konvalinka, A, Errett, L, \& Fong, I. W. Impact of treating Staphylococcus aureus nasal carriers on wound infections in cardiac surgery. J Hosp Infect. (2006). , 64, 162-8.

[68] Graf, K, Sohr, D, Haverich, A, Kühn, C, Gastmeier, P, \& Chaberny, I. F. Decrease of deep sternal surgical site infection rates after cardiac surgery by a comprehensive infection control program. Interact Cardiovasc Thorac Surg. (2009). , 9, 282-6.

[69] Saso, S, James, D, Vecht, J. A, Kidher, E, Kokotsakis, J, Malinovski, V, Rao, C, Darzi, A, Anderson, J. R, \& Athanasiou, T. Effect of skeletonization of the internal thoracic artery for coronary revascularization on the incidence of sternal wound infection. Ann Thorac Surg (2010). , 89, 661-70.

[70] Hirose, H, Amano, A, Takanashi, S, \& Takahashi, A. Skeletonized bilateral internal mammary artery grafting for patients with diabetes. Interact Cardiovasc Thorac Surg (2003). , 2, 287-92.

[71] Baskett RJF, MacDougall CE, Ross DB. Is mediastinitis a preventable complication? A 10-year review. Ann Thorac Surg (1999). , 67, 462-5.

[72] Robicsek, F, Daugherty, H. K, \& Cook, J. W. The prevention and treatment of sternum separartion following open-heart surgery J Thorac Cardiovasc Surg (1977). , 73, 267-268.

[73] Sharma, R, Puri, D, Panigrahi, B. P, \& Virdi, I. S. A modified parasternal wire technique for prevention and treatment of sternal dehiscence Ann Thorac Surg (2004). , 77, 210-213.

[74] Friberg, Ö, Dahlin, L. G, Söderquist, B, Källman, J, \& Svedjeholm, R. Influence of more than six sternal fixation wires on the incidence of deep sternal wound infection Thorac Cardiovasc Surg (2006). , 54, 468-473.

[75] Schimmer, C, Reents, W, Berneder, S, et al. Prevention of sternal dehiscence and infection in high-risk patients: a prospective randomized multicenter trial. Ann Thorac Surg (2008). , 86, 1897-904.

[76] Plass, A, Emmert, M. Y, Pilsl, M, Salzberg, S. P, Genoni, M, Falk, V, \& Grunenfelder, J. Sternal plate closure: indications, surgical procedure and follow-up. Thorac Cardiovasc Surg (2011). , 59, 30-3.

[77] Raman, J, Lehmann, S, Zehr, K, et al. Sternal Closure With Rigid Plate Fixation Versus Wire Closure: A Randomized Controlled Multicenter Trial. Ann Thorac Surg. (2012). doi:pii:S0003-4975(12)01863-2. 0.1016/j.athoracsur.2012.07.085. [Epub ahead of print] 
[78] Negri, A, Manfredi, J, Terrini, A, Rodella, G, Bisleri, G, El Quarra, S, \& Muneretto, C. Prospective evaluation of a new sternal closure method with thermoreactive clips. Eur J Cardiothorac Surg (2002). , 22, 571-5.

[79] Snyder, C. W, Graham, L. A, Byers, R. E, \& Holman, W. L. Primary sternal plating to prevent sternal wound complications after cardiac surgery: early experience and patterns of failure. Interact CardioVasc Thorac Surg (2009). , 9, 763-766.

[80] Bennett-guerrero, E, Phillips-bute, B, Waweru, P. M, Gaca, J. G, Spann, J. C, \& Milano, C. A. Pilot study of sternal plating for primary closure of the sternum in cardiac surgical patients. Innovations. (2011). , 6, 382-8.

[81] http://www.kci1.com/KCI1/prevena

[82] Stannard, J. P, Atkins, B. Z, Malley, O, Singh, D, Bernstein, H, Fahey, B, Masden, M, \& Attinger, D. CE. Use of negative pressure therapy on closed surgical incisions: a case series. Ostomy Wound Management (2009). , 55, 58-66.

[83] Wackenfors, A, Sjögren, J, Gustafsson, R, Algotsson, L, Ingemansson, R, \& Malmsjö, M. Effects of vacuum-assisted closure therapy on inguinal wound edge microvascular blood flow. Wound Repair Regen (2004). , 12, 600-6.

[84] Colli, A. First experience with a new negative pressure incision management system on surgical incisions after cardiac surgery in high risk patients. Journal of Cardiothoracic Surgery (2011).

[85] Atkins, B. Z, Wooten, M. K, Kistler, J, Hurley, K, \& Hughes, G. C. Wolfe WG: Does negative pressure wound therapy have a role in preventing poststernotomy wound complications? Surg Innov (2009).

[86] Robicsek, F. Postoperative Sterno-mediastinitis. Am Surg (2000). , 66, 184-192.

[87] Sarr, M. G, Gott, V. L, \& Townsend, T. R. Mediastinal infection after cardiac surgery. Ann Thorac Surg (1984).

[88] Shumacker, H. B, \& Mandelbaum, I. Continuous antibiotic irrigation in the treatment of infection. Arch Surg (1963).

[89] Merrill, W. H, Akhter, S. A, Wolf, R. K, \& Schneeberger, E. W. Flege JB Jr. Simplified treatment of postoperative mediastinitis..Ann Thorac Surg. (2004). , 78, 608-12.

[90] .Poncelet, A. J, Lengele, B, Delaere, B, et al. Algorithm for primary closure in sternal wound infection: a single institution 10-year experience. Eur J Cardiothorac Surg. (2008). , 33, 232-8.

[91] Kirsch, M, Mekontso-dessap, A, Houël, R, Giroud, E, Hillion, M. L, \& Loisance, D. Y. Closed drainage using redon catheters for poststernotomy mediastinitis: results and risk factors for adverse outcome.. Ann Thorac Surg. (2001). , 71, 1580-6. 
[92] Levi, N, \& Olsen, P. S. Primary closure of deep sternal wound infection following open heart surgery: a safe operation? J Cardiovasc Surg (Torino). (2000). Apr; 41(2), 241-5.

[93] Lee, A. B, Schimert, G, Shaktin, S, et al. Total excision of the sternum and thoracic pedicle transposition of the greater omentum; useful stratagems in managing severe mediastinal infection following open heart surgery. Surgery (1976). , 80, 433-6.

[94] Jurkiewicz, M. J, Bostwick, J, Hester, T. R, et al. Infected median sternotomy wound: successful treatment by muscle flaps. Ann Surg (1980).

[95] Jones, G, Jurkiewicz, M. J, et al. Management of the infected median sternotomy wound with muscle flaps. Ann Surg (1997). , 225, 766-78.

[96] Brandt, C, \& Alvarez, J. M. First-line treatment of deep sternal infection by a plastic surgical approach: superior results compared with conventional cardiac surgical orthodoxy. Plast Reconstr Surg. (2002). , 109, 2231-7.

[97] Wong CHK, Senewiratne S, Garlick G, Mullany D. Two-stage management of sternal wound infection using bilateral pectoralis major advancement flap. Eur J Cardiothorac Surg (2006). , 30, 148-152.

[98] Milano, C. A, Georgiade, G, Muhlbaier, L. H, Smith, P. K, \& Wolfe, W. G. Comparison of omental and pectoralis flaps for poststernotomy mediastinitis. Ann Thorac Surg (1999). , 67, 377-81.

[99] El Oakley, R. M, \& Wright, J. E. Postoperative mediastinitis: classification and management. Ann Thorac Surg (1996). , 61, 1030-6.

[100] Molina, E. Primary closure for infected dehiscence of the sternum. Ann Thorac Surg (1993). , 55, 459-63.

[101] Scully, H. E, Leclerc, Y, Martin, R. D, et al. Comparison between antibiotic irrigation and mobilization of pectoral muscle flaps in treatment of deep sternal infection. J Thorac Cardiovasc Surg (1985). , 90, 523-31.

[102] Rand, R. P, Cochran, R. P, Aziz, S, Hofer, B. O, Allen, M. D, Verrier, E. D, et al. Prospective trial of catheter irrigation and muscle flaps for sternal wound infection. Ann Thorac Surg (1998). , 65, 1046-1049.

[103] Ringelman, P. R, Vander, K. C, Cameron, D, Bumgartner, W. A, \& Manson, P. N. Long-term results of flap reconstruction in median sternotomy wound infection. Plast Reconstr Surg (1994). , 93, 1208-14.

[104] Pairolero, P. C, \& Arnold, P. C. Management of recalcitrant median sternotomy wounds. J Thorac Cardiovasc Surg (1984). , 88, 357-64.

[105] Levi, N, \& Olsen, P. S. Primary closure of deep sternal wound infection following open heart surgery: a safe operation? J Cardiovasc Surg (Torino). (2000). , 41, 241-5. 
[106] Nahai, F, Rand, R. P, Hester, T. R, et al. Primary treatment of the infected sternotomy wound with muscle flaps: a review of 211 consecutive cases. Plast Reconstr Surg (1989). , 84, 434-441.

[107] Kutsal, A, Ibrisim, E, Catav, Z, et al. Mediastinitis after open heart surgery. Analysis of risk factors and management. J Cardiovasc Surg (Torino) (1991). , 32, 38-41.

[108] Van Wingerden, J. J, Coret, M. E, Van Nieuwenhoven, C. A, \& Totté, E. R. The laparoscopically harvested omental flap for deep sternal wound infection. Eur J Cardiothorac Surg (2010). , 37, 87-92.

[109] Atkins, B. Z, Onaitis, M. W, Hutcheson, K. A, Kaye, K, Petersen, R. P, \& Wolfe, W. G. Does method of sternal repair influence long-term outcome of postoperative mediastinitis? Am J Surg. (2011). , 202, 565-7.

[110] Christian, M. The role of hyperbaric oxygen therapy in the treatment of sternal wound infectionEur J Cardiothorac Surg (2006). , 30, 153-159.

[111] Siondalski, P, Keita, L, Sicko, Z, Zelechowski, P, Jaworski, L, \& Rogowski, J. Surgical treatment and adjunct hyperbaric therapy to improve healing of wound infection complications after sterno-mediastinitis. Pneumonol Alergol Pol (2003). , 71, 12-16.

[112] Obdeijn, M. C, De Lange, M. Y, Lichtendahl, D. H, \& De Boer, W. J. Vacuum-assisted closure in the treatment of poststernotomy mediastinitis. Ann Thorac Surg (1999). , $68,2358-60$.

[113] Catarino, P. A, Chamberlain, M. H, Wright, N. C, Black, E, Campbell, K, Robson, D, \& Pillai, R. G. High-pressure suction drainage via a polyurethane foam in the management of poststernotomy mediastinitis. Ann Thorac Surg (2000). , 70, 1891-5.

[114] Gustafsson, R. I, Sjögren, J, \& Ingemansson, R. Deep sternal wound infection: a sternal-sparing technique with vacuum-assisted closure therapy. Ann Thorac Surg. (2003). , 76, 2048-53.

[115] Fleck, T. M, Fleck, M, Moidl, R, et al. The vacuum-assisted closure system for the treatment of deep sternal wound infections after cardiac surgery. Ann Thorac Surg (2002). , 74, 1596-600.

[116] Sjögren, J, Gustafsson, R, Nilsson, J, Lindstedt, S, Nozohoor, S, \& Ingemansson, R. Negative-pressure wound therapy following cardiac surgery: bleeding complications and 30-day mortality in 176 patients with deep sternal wound infection. Interact Cardiovasc Thorac Surg (2011). , 12, 117-20.

[117] Fleck, T, Moidl, R, Giovanoli, P, et al. A conclusion from the first 125 patients treated with the vacuum assisted closure system for postoperative sternal wound infection. Interact Cardiovasc Thorac Surg. (2006). , 5, 145-8. 
[118] Ennker, I. C, Malkoc, A, Pietrowski, D, Vogt, P. M, Ennker, J, \& Albert, A. The concept of negative pressure wound therapy (NPWT) after poststernotomy mediastinitis--a single center experience with 54 patients. J Cardiothorac Surg. (2009). Jan 12;4:5.

[119] Šimek, M, Kaláb, M, Molitor, M, et al. Topical negative pressure in the treatment of deep sternal infection following cardiac surgery: 5-year results of first-line application protocol. The EWMA Journal (2011). , 11, 38-41.

[120] Gustafsson, R, Johnsson, P, Algotsson, L, Blomquist, S, \& Ingemansson, R. Vacuumassisted closure therapy guided by C-reactive protein level in patients with deep sternal wound infection. J Thorac Cardiovasc Surg (2002). , 123, 895-900.

[121] Berg, H. F. Brands WGB, Geldrop van TR, Kluytmans-VandenBergh MFQ, Kluytmans JAJW. Comparison between closed drainage techniques for the treatment of postoperative mediastinitis. Ann Thorac Surg (2000). , 70, 924-929.

[122] Doss, M, Martens, S, Wood, J. P, Wolff, J. D, \& Baier, C. Moritz. Vacuum-assisted suction drainage versus conventional treatment in the management of poststernotomy osteomyelitis Eur J Cardiothorac Surg (2002). , 22, 934-938.

[123] Song, D. H, Wu, L. C, Lohman, R. F, Gottlieb, L. J, \& Franczyk, M. Vacuum-assisted closure for the treatment of sternal wounds: the bridge between debridement and definitive closure. Plast Reconstr Surg (2003). , 111, 92-97.

[124] Luckraz, H, Murphy, F, Bryant, S, Charman, S, \& Ritchie, A. Vacuum-assisted closure as a treatment modality for infections after cardiac surgery J Thorac Cardiovasc Surg (2003). , 125, 301-305.

[125] Fuchs, U, Zittermann, A, Stuetten, B, Groening, A, Minami, K, \& Koefer, R. Clinical outcome of patients with deep sternal infection managed by vacuum-assisted closure compared to conventional therapy with open packing: A retrospective analysis. Ann Thorac Surg (2005). , 79, 526-31.

[126] Sjögren, J, Gustafsson, R, Nilsson, J, Malmsjö, M, \& Ingemansson, R. Clinical outcome after poststernotomy mediastinitis: vacuum-assisted closure versus conventional treatment. Ann Thorac Surg. (2005). , 79, 2049-55.

[127] Immer, F. F, Durrer, M, Mühlemann, K. S, Erni, D, Gahl, B, \& Carrel, T. P. Deep sternal wound infection after cardiac surgery: modality of treatment and outcome. Ann Thorac Surg. (2005). , 80, 957-61.

[128] Segers, P, De Jong, A. P, \& Kloek, J. J. de Mol BAJM. Poststernotomy mediastinitis: comparison of two treatment modalities. Interact Cardiovasc Thorac Surg (2005). , 4 , 555-560.

[129] Petzina, R, Hoffmann, J, Navasardyan, A, et al. Negative pressure wound therapy for post-sternotomy mediastinitis reduces mortality rate and sternal re-infection rate compared to conventional treatment.Eur J Cardiothorac Surg (2010). , 38, 110-3. 
[130] Simek, M, Hajek, R, Fluger, I, et al. Superiority of topical negative pressure over closed irrigation therapy of deep sternal wound infection in cardiac surgery. J Cardiovasc Surg (Torino) (2012). , 53, 113-20.

[131] De Feo, M. Della Corte A, Vicchio M, Pirozzi F, Nappi G, Cotrufo M. Is post-sternotomy mediastinitis still devastating after the advent of negative-pressure wound therapy? Tex Heart Inst J (2011). , 38, 375-80.

[132] Assmann, A, Boeken, U, Feindt, P, Schurr, P, Akhyari, P, \& Lichtenberg, A. Vacuumassisted wound closure is superior to primary rewiring in patients with deep sternal woundinfection. Thorac Cardiovasc Surg (2011). , 59, 25-9.

[133] Vos, R. J, Yilmaz, A, Sonker, U, Kelder, J. C, \& Kloppenburg, G. T. Vacuum-assisted closure of post-sternotomy mediastinitis as compared to open packing. Interact Cardiovasc Thorac Surg. (2012). , 14, 17-21.

[134] Deniz, H, Gokaslan, G, Arslanoglu, Y, Ozcaliskan, O, Guzel, G, Yasim, A, \& Ustunsoy, $\mathrm{H}$. Treatment outcomes of postoperative mediastinitis in cardiac surgery; negative pressure wound therapy versus conventional treatment. J Cardiothorac Surg (2012).

[135] Fleck, T, \& Fleck, M. Negative pressure wound therapy for the treatment of sternal wound infections after cardiac surgery. Int Wound J (2012). doi:j.X.2012.01079.x. [Epub ahead of print], 1742-481.

[136] Raja, S. G, \& Berg, G. A. Should vacuum-assisted closure therapy be routinely used for management of deep sternal wound infection after cardiac surgery? Interact CardioVasc Thorac Surg (2007). , 6-523.

[137] Schimmer, C, Sommer, S. P, Bensch, M, Elert, O, \& Leyh, R. Management of poststernotomy mediastinitis: experience and results of different therapy modalities.Thorac Cardiovasc Surg. (2008). , 56, 200-4.

[138] Damiani, G, Pinnarelli, L, Sommella, L, Tocco, M. P, Marvulli, M, Magrini, P, \& Ricciardi, W. Vacuum-assisted closure therapy for patients with infected sternal wounds: a meta-analysis of current evidence. J Plast Reconstr Aesthet Surg (2011). , 64, 1119-23.

[139] De Feo, M, Vicchio, M, Nappi, G, \& Cotrufo, M. Role of vacuum in methicillin-resistant deep sternal wound infection.Asian Cardiovasc Thorac Ann. (2010). , 18, 360-3.

[140] Al-ebrahim, K. E. Sternocutaneous fistulas after cardiac surgery. Ann Thorac Surg (2010). , 89, 1705-6.

[141] Gaudreau, G, Costache, V, Houde, C, Cloutier, D, Montalin, L, Voisine, P, \& Baillot, R. Recurrent sternal infection following treatment with negative pressure wound therapy and titanium transverse plate fixation. Eur J Cardiothorac Surg. (2010). , 37, 888-92. 
[142] Steingrímsson, S, Gustafsson, R, Gudbjartsson, T, Mokhtari, A, Ingemansson, R, \& Sjögren, J. Sternocutaneous fistulas after cardiac surgery: incidence and late outcome during a ten-year follow-up. Ann Thorac Surg (2009). , 88, 1910-5.

[143] Darouiche, R. O. Treatment of infections associated with surgical implants.N Engl J Med (2004). , 350, 1422-9.

[144] Bu-omar, Y, Naik, M. J, Catarino, P. A, \& Ratnatunga, C. Right ventricular rupture during use of high-pressure suction drainage in the management of poststernotomy mediastinitis. Ann Thorac Surg. (2003).

[145] Bapat, V, Muttardi, N, Young, C, Venn, G, \& Roxburgh, J. Experience with Vacuumassisted closure of sternal wound infections following cardiac surgery and evaluation of chronic complications associated with its use. J Card Surg. (2008). , 23, 227-33.

[146] Van Wingerden, J. J, Segers, P, \& Jekel, L. Major bleeding during negative pressure wound/V.A.C.®--therapy for postsurgical deep sternal wound infection--a critical appraisal. J Cardiothorac Surg. 201;6:121.

[147] Hayward, R. H, Korompai, F. L, \& Knight, W. L. The open sternotomy wound and risk of acute hemorrhage. J Thorac Cardiovasc Surg (1992). , 103, 1228-30.

[148] Khoynezhad, A, Abbas, G, Palazzo, R. S, \& Graver, L. M. Spontaneous right ventricular disruption following treatment of sternal infection. J Card Surg (2004). , 19, 74-8.

[149] Niclauss, L, Delay, D, \& Stumpe, F. Right ventricular rupture due to recurrent mediastinal infection with a closed chest. Interact Cardiovasc Thorac Surg (2010). , 10, $470-2$.

[150] Petzina, R, Malmsjö, M, Stamm, C, \& Hetzer, R. Major complications during negative pressure wound therapy in poststernotomy mediastinitis after cardiac surgery. J Thorac Cardiovasc Surg.(2010). , 140, 1133-6.

[151] Malmsjö, M, Petzina, R, Ugander, M, Engblom, H, Torbrand, C, Mokhtari, A, Hetzer, $\mathrm{R}$, Arheden, $\mathrm{H}$, \& Ingemansson, $\mathrm{R}$. Preventing heart injury during negative pressure wound therapy in cardiac surgery: assessment using real-time magnetic resonance imaging. J Thorac Cardiovasc Surg (2009). , 138, 712-7.

[152] Voss, B, Bauernschmitt, R, Will, A, et al. Sternal reconstruction with titanium plates in complicated sternal dehiscence. Eur J Cardiothorac Surg (2008). , 34, 139-145.

[153] Gaudreau, G, Costache, V, Houde, C, Cloutier, D, Montalin, L, Voisine, P, \& Baillot, R. Recurrent sternal infection following treatment with negative pressure wound therapy and titanium transverse plate fixation. Eur J Cardiothorac Surg (2010). , 37, 888-92.

[154] Voss, B, Bauernschmitt, R, Brockmann, G, et al. Osteosynthetic thoracic stabilization after complete resection of sternum. Eur J Cardiothorac Surg (2007). , 32, 391-393. 
[155] Piotrowski, J. A, Fischer, M, Klaes, W, \& Splittgerber, F. Autologous bone transplant after sternal resection. J Cardiovasc Surg (Torino) (1996). , 37, 179-81.

[156] Nahabedian, M. Y, Riley, L. H, Greene, P. S, et al. Sternal stabilization using allograft fibula following cardiac transplantation. Plastic Reconstr Surg (2001). , 108, 1284-8.

[157] Marulli, G, Hamad, A. M, Cogliati, E, Breda, C, Zuin, A, \& Rea, F. Allograft sternochondral replacement after resection of large sternal chondrosarcoma. J Thorac Cardiovasc Surg (2010). e, 69-70.

[158] Dell'amore A, Cassanelli N, Dolci G, Stella F.An alternative technique for anterior chest wall reconstruction: the sternal allograft transplantation. Interact Cardiovasc ThoracInteract Cardiovasc Thorac Surg. (2012). , 15, 944-7.

[159] Dell'Amore A, Dolci G, Cassanelli N, Bini A, Stella F.A massive post-sternotomy sternal defect treated by allograft sternal transplantation. J Card Surg (2012). , 27, $557-9$.

[160] Kalab, M, Molitor, M, Kubesova, B, \& Lonsky, V. Use of allogenous bone graft and osteosynthetic stabilization in treatment of massive post-sternotomy defects. Eur J Cardiothorac Surg. (2012). Jun;41(6):e, 182-4.

[161] Collection of Laws of The Czech RepublicAct (2008). Collegium on Human Tissues and Cells. Prague, 2008.(296)

[162] European Association of Tissue BanksGeneral Standards for Tissue Banking. ÖBIGTransplant, Vienna, (1995).

[163] Perkins, D. J, Hunt, J. A, Pennington, D. G, \& Stern, H. S. Secondary sternal repair following median sternotomy using interosseous absorbable sutures and pectoralis major myocutaneous advancement flaps. British J Plast Surg (1996). , 49, 214-219.

[164] Brito, J. D, Assumpcao, C. R, Murad, H, \& Jazbik, A. P. Sa MPL, Bastos ES, Giambroni Filho R, Silva RS. One-stage management of infected sternotomy wounds using bilateral pectoralis major myocutaneous advancement flap. Rev Bras Cir Cardiovasc (2009). , 24, 58-63.

[165] Greig AVH, Geh JLC, Khanduja V, Shibu M.Choice of flap for the management of deep sternal wound infection- an anatomical classification. J Plast Reconstr Aesth Surg. (2007). , 60, 372-378.

[166] Salgado, C. J, Mardini, S, Mamali, A. A, Ortiz, J, Gonzales, R, \& Chen, H. C. Muscle versus nonmuscle flaps in the reconstructon of chronic osteomyelitis defects. Plast Reconstr Surg, (2006). , 118, 1401-1411.

[167] Yazar, S, Lin, Y. T, Ulusal, A. E, \& Wei, F. C. Outcome comparison between free muscle and free fasciocutaneous flaps for reconstruction of distal third and ankle traumatic opetn tibial fractures. Plast Reconstr Surg, (2006). , 117, 2468-2475. 
[168] Serafin, D. The Pectoralis Major Muscle Flap. In Serafin D. Atlas of Microsurgical Composite Tissue Tranplantation. W.B.Saunders company, London, (1996). , 1996, 161-174.

[169] Netscher, D. T, Eladoumikdachi, F, Mchugh, P. M, Thornby, J, \& Soltero, E. Sternal wound debridement and muscle flap reconstruction: functional implications. Annals of Plast Surg (2003). , 51, 115-122.

[170] Cohen, M, Yaniv, Y, Weiss, J, Greif, J, Gur, E, Wertheym, E, \& Shafir, R. Median sternotomy wound complication: the effect of reconstruction on lung function. Annals Plast Surg (1997). , 39, 36-43.

[171] Arnold, P. G, \& Pairolero, P. C. Chest-wall reconstruction. An account of 500 consecutive patients. Plast Reconstr Surg (1996). , 98, 804-810.

[172] Skoracki, R. J, \& Chang, D. W. Reconstruction of the chestwall and thorax. J Surg Oncol (2006). , 94, 455-465.

[173] Ascherman, J. A, Patel, S. M, Malhotra, S. M, \& Smith, C. R. Management of sternla wounds with bilateral pectoralis major myocutaneous advancement flaps in 114 consecutively treated patients: refinements in technique and outcomes analysis. Plast Reconstr Surg (2004). , 114, 676-83.

[174] Hugo, N. E, Sultan, M. R, Ascherman, J. A, Patsis, M. C, Smith, C. R, \& Rose, E. A. Single-stage management of 74 consecutive sternla wound complications with pectoralis major myocutaneous advancement flaps. Plast Reconstr Surg (1994). , 93, 1433-1441.

[175] Brutus, J. P, Nikolis, A, Perreault, I, \& Harris, P. G. The unilateralpectoralis major island flap, an efficient and straightforward procedure for reconstruction of full length sternal defects after postoperative mediastinal wound infection. Brit J Plast Surg (2004). , 57, 803-805.

[176] Chou, E, Tai, Y, Chen, H, \& Chen, K. Simple and reliable way in sternum wound coverage-tripedicle pectoralis major musculocutaneous flap. Microsurgery. (2008). , 28, 441-6.

[177] Majure, J. A, Albin, R. E, Donnell, O, \& Arganese, R. S. TJ. Reconstruction of the infected median sternotomy wound. Ann Thorac Surg (1986). , 42, 9-12.

[178] Molitor, M, Simek, M, Lonský, V, Kaláb, M, Veselý, J, \& Zálešák, B. Pectoral muscle flap with v-y skin paddle for covering sternal defects. Ann Thorac Surg. (2012). e, 131-3.

[179] Hallock, G. G. The breast musculocutaneous flap for complete coverage of the median sternotomy wound. Plast Reconstr Surg (2003). , 112, 199-203. 
[180] Nahai, F, Morales, L, Bone, D. K, \& Botswick, J. Pectoralis Major Muscle Turnover Flaps for Closure of the infected Sternotomy Wound with Preservation of Form and Function. Plast Reconstr Surg (1982). , 70, 471-474.

[181] Spiess, A. M, Balakrishnan, C. H, \& Gursel, E. Fascial release of the pectoralis major:a technique used in pectoralis major muscle closure of the mediastinum in cases of mediastinitis. Plast Reconstr Surg. (2007). , 119, 573-7.

[182] Serafin, D. The Pectoralis Major Muscle Flap. In Serafin D. Atlas of Microsurgical Composite Tissue Tranplantation. W.B.Saunders company, London, (1996). , 1996, 221-247.

[183] Skoracki, R. J, \& Chang, D. W. Reconstruction of the chestwall and thorax. J Surg Oncol. (2006). Review., 94, 455-65.

[184] Acinapura, A. J, Godfrey, N, Romita, M, Cunningham, J, Adams, P. X, Jacobowitz, I. S, Rose, D. M, \& Nealon, T. Surgical management of infected median sternotomy:Closed irrigation vs muscle flaps. J Cardiovasc. Surg (1985). , 26, 443-446.

[185] Ford, T. D. Rectus abdominis myocutaneous flap used to close a median sternotomy chest defect. S Afr Med J (1985). , 68, 115-116.

[186] Solomon, M. P, \& Granick, M. S. Bipedicle muscle flaps in sternal wound repair. Plast Reconstr Surg. (1998). , 101, 356-6.

[187] Laitung JKG, Peck F. Shoulder function following the loss of the latissimus dorsi muscle. British J Plast Surg (1985). , 38, 375-379.

[188] Dejesus, R. A, Paletta, J. D, \& Dabb, R. W. Reconstruction of the median sternotomy sound dehiscence using the latissimus dorsi myocutaneous flap. J Cardiovasc Surg (2001). , 42, 359-564.

[189] Fansa, H, Handstein, S, \& Schneider, W. Treatment of infected median sternotomy wounds with a myocutaneous latissimus dorsi muscle flap. Scand Cardiovasc J (1998). , 32, 33-39.

[190] Roshan, A, Kotwal, A, \& Riaz, M. Stanley PRW. Sternal wound dehiscence complicated by macromastia: report of two cases with discussion of literature. J Plast Reconstr Aesth Surg (2009). ee364., 362.

[191] Copeland, M, Senkowski, C, Ergin, A, et al. Macromastia as a factor in sternal wound dehiscence following cardiac surgery:management combining chest wall reconstruction and reduction mammaplasty. J Card Surg (1992). , 7, 275-278.

[192] Fontaine, S, Devos, S, \& Goldschmidt, D. Reduction mammoplasty combined with pectoralis major muscle flaps for median sternotomy wound closure. Br J Plats Surg (1996). , 49, 220-222. 
[193] Uygur, F, Sever, C, Ulkur, E, \& Celikoz, B. Reconstruction of large post-sternotomy wound with bilateral V-Y fasciocutaneous advancement flaps. Ann Thorac Surg (2008). , 86, 1012-1015.

[194] Roshan, A, Kotwal, A, \& Riaz, M. Stanley PRW. Sternal wound dehiscence complicated by macromastia: report of two cases with discussion of literature. J Plast Reconstr Aesth Surg (2009). ee364., 362.

[195] Würinger, E, Mader, N, Posch, E, \& Holle, J. Nerve and vessel supplying ligamentous suspension of the mammary gland. Plast Reconstr Surg (1998). , 101, 1486-1493.

[196] Hamdi, M, \& Dancey, A. The septum-based therapeutic mammaplasty technique for management of sternal defects. Plast Reconstr Surg (2010). , 569-573.

[197] Hughes, K. C, Henry, M. J, Turner, J, \& Manders, E. K. Design of the cyclops flap for chest-wall reconstruction. Plast Reconstr Surg (1997). , 100, 1146-51.

[198] Aydin, A, Güven, E, Keklik, B, Basaran, K, \& Özkan, B. Reconstruction of the Chest Wall Defects with Mammary Dermoglandular Advancement Flaps in Female Complicated Cases. Trakya Univ Tip Fak Derg (2009). , 26, 130-133.

[199] Yasuura, K, Okamoto, H, Morita, S, Ogawa, Y, Sawazaki, M, Seki, A, Masumoto, H, Matsuura, A, Maseki, T, \& Torii, S. Results of omental flap transposition for deep sternal wound infection after cardiovascular surgery. Annals of Surg (1998). , 227, 455-459.

[200] Mathisen, D. J, Grillo, H. C, Vlahakes, G. J, et al. The omentum in the management of complicated cardiothoracic probleme. J Thorac Cardiovasc Surg (1988). , 95, 677-684.

[201] Weinzweig, N, \& Hetman, R. Transposition of the greater omentum for recalcitrant median sternotomy wound infection. Annals Plast. Surg (1995). , 34, 471-477.

[202] Alday, E. S, \& Golsdmith, H. S. Surgical technique for ometal lenghtening based on arterial anatomy. Surg Gynecol Obstet (1972).

[203] Das, S. K. The size of the human omentum and methods of lenghtening it for transposition. Br J Plast Surg (1976). , 29, 170-174.

[204] Weinzweig, N, \& Hetman, R. Transposition of the greater omentum for recalcitrant median sternotomy wound infection. Annals Plast. Surg (1995). , 34, 471-477.

[205] Pearl, S. N, \& Dibbell, D. G. Reconstruction after median sternotomy infection. Surg Gynecol Obstet (1984). , 159, 47-52.

[206] Colen, L. B, Huntsman, W. T, \& Morain, W. D. The integrated approach to suppurative mediastinitis: rewiring the sternum over transposed omentum. Plast Reconstr Surg (1989). , 84, 936-943.

[207] Hakelius, L. Fatal complication after use of the greater omentum for reconstruction of the chest wall. Plast Reconstr Surg (1978). 
[208] Acarturk, T. O, Swartz, W. M, Luketich, J, et al. Laparoscopically harvested omental flap for chest wall and intrathoracic reconstruction. Ann Plast Surg (2004). , 53, 210-216.

[209] Barragan, B. A, Hallodorsson, A. O, Wachtel, M. S, \& Frezza, E. E. Laparoscopic greater omentum harvesting with split-thickness skin grafting for sternal wound dehiscence. The American Surgeon (2006). , 72, 829-832.

[210] Reichenberger, M. A, Harenberg, P. S, Pelzer, M, Gazyakan, E, Ryssel, G, Hermann, G, \& Engel, H. Arteriovenous loops in microsurgical free tissue transfer in reconstruction of central sternal defects. J Thorac Cardiovasc Surg (2010). , 140, 1283-1287.

[211] Engel, H, Pelzer, M, Sauerbier, M, Hermann, G, \& Heitmann, C. An innovative treatment concept for free flap reconstruction of komplex central chest wall defects- the cephalic-thoraco-acromial (CTA) loop. Microsurgery (2007). , 27, 481-486. 
